\title{
Marine protected areas for demersal elasmobranchs in highly exploited
}

\section{Mediterranean ecosystems}

Joan Giménez ${ }^{\mathrm{a}, \mathrm{b}, \mathrm{c}^{*}}$, Laura Cardador ${ }^{\mathrm{d}}$, Tessa Mazor ${ }^{\mathrm{e}}$, Salit Kark ${ }^{\mathrm{f}}$, José Maria Bellido ${ }^{\mathrm{g}}$, Marta Coll ${ }^{\mathrm{a}}$ and Joan

Navarro $^{\mathrm{a}}$

a Institut de Ciències del Mar - CSIC, Passeig Marítim de la Barceloneta 27-49, 08003 Barcelona, Spain.

${ }^{\mathrm{b}}$ MaREI Centre, Environmental Research Institute, University College Cork, Cork, Ireland.

${ }^{\mathrm{c}}$ School of Biological, Earth \& Environmental Sciences (BEES), University College Cork, Distillery Fields, North Mall, Cork, Ireland.

${ }^{\mathrm{d}}$ Centre de Recerca Ecològica i Aplicacions Forestals (CREAF), Cerdanyola del Vallès, 08193, Spain.

${ }^{\mathrm{e}}$ School of Biological Sciences, The University of Queensland, Brisbane, Queensland, Australia.

${ }^{\mathrm{f}}$ The Biodiversity Research Group, The School of Biological Sciences, Centre for Biodiversity and Conservation Science, The University of Queensland, Brisbane, Queensland, Australia.

${ }^{\mathrm{g}}$ Instituto Español de Oceanografía (IEO), Centro Oceanográfico de Murcia, Calle Varadero 1, Apdo. 22, San Pedro del Pinatar, 30740 Murcia, Spain.

*Corresponding author: joan.gimenez@csic.es

Citation: Giménez, J., Cardador, L., Mazor, T., Kark, S., Bellido, J. M., Coll, M., \& Navarro, J. (2020). Marine protected areas for demersal elasmobranchs in highly exploited Mediterranean ecosystems. Marine Environmental Research, 160, 105033. 


\begin{abstract}
Marine ecosystems are complex socio-ecological systems where sustainable solutions can be best gained by satisfying both conservation and socioeconomic demands. Concretely, the Mediterranean Sea is facing a huge demand of resources and marine activities while hosting abundant and unique biodiversity. It is considered an important elasmobranch hotspot where seventy-two elasmobranch species are present in the basin. Despite the recognised importance of elasmobranchs as umbrella species, to date only a small number of marine protected areas have been designated towards their protection. The paucity of spatially-explicit abundance data on elasmobranchs often precludes the designation of these areas to protect these marine predators. Here, we aimed to identify marine areas to protect elasmobranch species by means of a systematic spatial planning approach. We first estimated the spatial distribution of five elasmobranch species (three sharks and two rays) in the western Mediterranean Sea and then applied Marxan decision support tools to find priority marine conservation areas. We found that the five elasmobranchs are distributed in coastal and slope areas of the southern waters of the study area while in the northern region they are abundant in the continental slope and towards offshore waters. Conservation priority areas were identified in the southern part of the western Mediterranean. Adding more complex cost layers and zoning to the analysis did not alter conservation priority areas, confirming such areas are highly consistent and highly important for elasmobranch protection. The marine conservation priority areas identified here can contribute to designate a proactive area-based protection strategy towards elasmobranch conservation, related species and the habitats that they depend in the western Mediterranean Sea.
\end{abstract}




\section{INTRODUCTION}

Several human activities, such as fishing, industrial activity, energy production between others, take place in natural environments worldwide with significant deleterious effects on ecosystems, including marine ecosystems (Halpern et al., 2015; Venter et al., 2016). Such effects in the oceans are expected to expand into deeper and more distant marine areas as "blue growth" strategies are promoted (Katsanevakis et al., 2017). Threats imposed by humans are ubiquitous and are causing important changes in marine biodiversity and ecosystems functioning (Halpern et al., 2015; Jackson et al., 2001). Exploitation, pollution, eutrophication and habitat loss are among the most impacting for the survival and conservation of marine species (Halpern et al., 2015). Additionally, other growing impacts such as climate change or the introduction of alien species are of concern (Kelleher, 1999; Korpinen and Andersen, 2016; Pomeroy et al., 2005).

Policymakers face increasing pressure to design and apply effective and robust regulations to preserve marine biodiversity. One common approach is the implementation of Marine Protected Areas (MPAs) spatially designed and managed to protect marine ecosystems, habitats and species (Agardy, 1997). Sitebased approaches, such as MPAs, can enhance biodiversity conservation if they are designed with a sciencebased approach, accounting for areas of high abundance of species of conservation concern or focal biodiversity targets as well as the distribution of their main threats (Davidson and Dulvy, 2017) and with an effective enforcement regime (Horta e Costa et al., 2016).

Predators and other marine megafauna have been proposed as useful organisms to define and identify MPAs because their spatial distribution and population parameters integrate seasonal spatial and abundance variation of lower trophic levels and on broad areas (Hooker and Gerber, 2004; Ronconi et al., 2012, but see Sergio et al. 2008). They can act as a biodiversity surrogates when other biodiversity data is not available. In some cases, imperilled species lack spatial-explicit abundance data because they are rare and thus difficult to track and, so relying in species that are more abundant but with similar ecological requirement may serve as a good surrogate to use in marine spatial planning. Marine predators have been, in turn, strongly impacted by human activities, and several species and taxa are currently considered of immediate conservation concern (Hooker et al., 2011; Daly et al., 2018). Top consumers such as some marine mammals and seabirds 
are commonly used as focal species to designate MPAs (e.g., Afán et al., 2018; Arcos et al., 2012; Evans, 2018; Gormley et al., 2012). In comparison, sharks and rays have been overlooked (Davidson and Dulvy, 2017; MPAtlas, 2016) but they also need spatial-explicit protection. Their life-history characteristics such as low fecundity, slow growth and late reproductive maturity make them highly vulnerable to human activities (Coelho and Erzini, 2008; Frisk et al., 2005; García et al., 2008; Rigby and Simpfendorfer, 2015). As well as the fact that they are targeted for food and medicinal use (unlike seabirds and marine mammals), and suffer high mortality due to fishery by-catch (Clarke et al., 2006). The depletion of the populations of sharks and rays can lead, in turn, to important cascading effects on lower trophic levels (Ferretti et al., 2010; Myers et al., 2007) so their protection can serve as a proactive strategy (i.e. before the species or habitats become threatened) to conserve the whole marine food web.

Awareness of the vulnerability and ecological role of elasmobranchs is leading to increased conservation attention (Barría et al., 2015; Davidson and Dulvy, 2017; Gallagher et al., 2012). The European Commission, in particular, adopted in 2009 the first Action Plan for the conservation and management of elasmobranchs to reverse the impacts of shark depletions and rebuild stocks under threat (EU, 2009). This plan considers the implementation of management actions to protect priority elasmobranch habitats, the reduction of fisheries by-catch, and the study of current and expected impacts to design efficient strategies for the preservation of elasmobranch biodiversity (Katsanevakis et al., 2009). Even so, in some geographic areas such as the Mediterranean Sea, which is considered an important elasmobranch hotspot of extinction risk at global scale (Dulvy et al., 2014), existing marine protected areas do not guarantee current European species targets (Micheli et al., 2013; Coll et al., 2015). Declines of both medium- and large-size elasmobranchs have been observed in the last decades (Ferretti et al., 2008; IUCN, 2019) and only few species still remain in highly impacted sites (Aldebert, 1997; Coll et al., 2013; Ferretti et al., 2008; Malak et al., 2011). These negative trends could reflect a lack of representation of elasmobranchs species in existing marine protected areas, as they were not explicitly accounted for in current MPA design (MPAtlas, 2016).

In this study, we aimed for first time to identify priority areas for protecting the demersal elasmobranch community in the western Mediterranean Sea. We applied a systematic conservation planning approach comparing identifyed priorities with the current MPA network to evaluate its usefulness in relation to the management of demersal elasmobranchs. Due to the scarce information regarding the spatial 
distribution of demersal sharks and rays, here we focused on five species of elasmobranch (three sharks and two rays), for which accurate abundance and distribution data is available from a long-term systematic survey conducted in the Mediterranean Sea (Bertrand et al., 2000). These species encompass a wide range of ecological requirements and their well-documented distribution can be informative of ecologically relevant areas for the wider demersal elasmobranch community, formerly more diverse and nowadays much degraded (Aldebert, 1997; García et al., 2008; Rigby and Simpfendorfer, 2015; Simpfendorfer and Kyne, 2009).

As a first step, we identified areas of high ecological value by analysing the spatial distribution of abundances of the five selected species and their relationships with main environmental variables. We then explored different conservation planning alternatives by considering both the distribution and their main threat (i.e. fishing activity) and also including other potential threats (surface temperature anomalies, concentration of pesticides and fertilizers, ocean pollution, and inorganic pollution) in a cost-effectiveness framework (Watts et al., 2017). Increased levels of complexity were considered in the analyses by accounting separately for single or multiple threats combinations as well as by considering different zonation plans limiting local human use (fisheries) at different levels in different parts of the protected areas.

\section{MATERIAL AND METHODS}

\section{Study area}

The study area included the Spanish continental shelf and upper slope (up to $800 \mathrm{~m}$ depth) of the western Mediterranean Sea, from the "Cap de Creus" in the north to the "Cabo de Palos" in the south (Fig. 1). This area has been identified as a highly impacted marine area within the Mediterranean Sea, where multiple threats operate simultaneously (Coll et al., 2012; Micheli et al., 2013a; Ramírez et al., 2018). Despite these impacts, the area still hosts relative high levels of marine diversity and endemicity (Coll et al., 2015, 2012, 2010), including elasmobranchs (Barría et al., 2015; Coll-Calvo et al., 2020; Coll et al., 2013; Navarro et al., 2016, 2015). Topographic and hydrographic features present a latitudinal gradient in the area (Estrada, 1996). The continental shelf broadens in the south, and it is widest around the Ebro Delta (Fig. 1). This area is highly productive due to the run-off from the Ebro River and the Liguro-Provençal-Catalan 
current (Estrada, 1996). In the northern area, the continental shelf is narrower and the Liguro-ProvençalCatalan current flows south-westwards along the continental slope. These oceanographic features make the area an important fishing grounds in the Mediterranean Sea, with a large fishing fleet operating in the region (FAO, 2018; Papaconstantinou and Farrugio, 2000).

\section{Study species}

We focussed on three sharks, the small-spotted catshark Scyliorhinus canicula, the blackmouth catshark Galeus melastomus and the velvet belly lanternshark Etmopterus spinax, and two rays, the Mediterranean starry ray Raja asterias, and the marbled electric ray Torpedo marmorata. Although only the Mediterranean starry ray $R$. has considered as Near Threatened (Serena et al., 2015) and the other species are of least concern by the International Union for Conservation of Nature (IUCN), they are the most abundant elasmobranch species in the highly exploited Mediterranean marine ecosystems, where other Gulf of Lions or the Balearic Sea during the last decades such, for example, angelsharks (Squatina spp.), nursehood shark (Scyliorhinus stellaris) or guitarfish (Rhinobatos spp.) (Coll et al., 2014). Moreover, as it occurs with other abundant elasmobranch species worldwide (Worm et al. 2013, Dulvy et al 2014), it has been documented a decrease in the conservation status of these relative common species in different areas of the Mediterranean Sea such as the Gulf of Lions or the Balearic Sea(Aldebert, 1997; Coll et al., 2010; García et al., 2008; Mendoza et al., 2014; Pennino et al., 2013; Rigby and Simpfendorfer, 2015; Simpfendorfer and Kyne, 2009). Also, elasmobranch species are per se an important marine group to focus on because of a range of reasons, including their potential to serve as umbrella species, flagship, or indicator species (Ferretti et al., 2008; Myers et al., 2007; Stevens, 2000). Moreover, since these five elasmobranchs encompass a wide range of ecological requirements (i.e. different depth ranges, trophic preferences and behavioral patterns), we expect that the results are representative of the wider demersal elasmobranch community in the western Mediterranean Sea.

S. canicula is distributed from 100 to 1500 depth (Gouraguine et al., 2011; Navarro et al., 2016) and preys mainly on crustaceans (Valls et al., 2011; Barría, Navarro, \& Coll, 2018). G. melastomus and E. spinax are distributed from 200 to $1400 \mathrm{~m}$ (Gouraguine et al., 2011), consuming diverse prey such crustaceans, cephalopods and fish (Valls et al., 2011; Barría, Navarro, \& Coll, 2018). R. asterias is a 
medium-size Mediterranean endemic skate (Hureau et al., 1984) inhabiting shallow demersal waters (mostly found to a depth of 100-200 m; Navarro et al. 2016) and has shown declines with time associated to benthic fishing trawling (Coll et al., 2013). It is considered a crustacean-specialist, mainly preying on benthic crabs (Navarro et al., 2013; Barría, Coll, \& Navarro, 2015). T. marmorata is distributed between 20-400 m depth (Capapé and Desoutter, 1990) and preys upon fish and cephalopods, although small proportions of crustaceans were also found as part of its diet (Capapé et al., 2007; Barría, Coll, \& Navarro, 2015). Based on the very few information published about their spatial movements, we could consider that they are resident and present in the same area during all year (Sims et al 2001).

\section{Elasmobranch distributions}

\section{i) Survey design and data}

The spatial data used in the present study were obtained from the European Union Mediterranean Trawl Survey Program (MEDITS) developed between the years 2002-2012 in the western Mediterranean Sea (Fig. 1). MEDITS surveys were carried out during the early summer period (May-July) and included standardized sampling with a bottom-trawl (60 minutes of duration) at predefined stations over the coastal and continental shelf areas and the upper slopes from 10 to $800 \mathrm{~m}$ depth (MEDITS protocol; Bertrand et al. (2008)). Sampling stations were placed randomly through the study area and sampling was performed in similar locations during all years. The MEDITS protocol uses a codent mesh size of $10 \mathrm{~mm}$ (stretched mesh), and the minimum size of individuals captured measured $2.5 \mathrm{~cm}$. The location of each sampling station was incorporated into a Geographic Information System using the world projection WGS European 1984 in a grid of $0.1^{\circ}$ resolution covering the whole study area. A total of 169 cells of this grid were surveyed (average of $70 \pm 8$ cells sampled each year; see Fig. 1). For each cell we calculated the abundance of each species (average of the number of individuals per $\mathrm{km}^{2}$ across all sampling years). Normality and heteroscedasticity of the abundance values was tested by using Shapiro-Wilk tests with the R software package MVN (Korkmaz et al., 2014). Based on these tests, abundance values were log-transformed before applying ANOVA tests. Then, we considered the average abundance across all sampling years in each cell for subsequent analyses because species abundances did not differ between years when using two-way 
ANOVA tests considering the factors year, cell and the interaction between both factors (P ranged $0.45-0.91$ for years; and for the interaction year $\times$ cell $\mathrm{P}$ ranged $0.06-0.90)$. We considered abundances $=0$ in the cells where a particular species never was recorded during the sampling years.

\section{ii) Environmental and spatial variables}

The environmental variables included were: a) chlorophyll-a concentration (CHL, mg C m-3); b) sea surface temperature (SST, $\left.\left.{ }^{\circ} \mathrm{C}\right) ; \mathrm{c}\right)$ depth $\left.(\mathrm{DEPTH}, \mathrm{m}) ; 4\right)$ dissolved-oxygen $(\mathrm{DO}, \mathrm{ml} \mathrm{l-1)}$, and d) sea surface salinity (SSS). SST and CHL were obtained from the Aqua MODIS sensor and were extracted from the seasonal average estimates corresponding to the MEDITS survey period (May-July) for 2002-2012. The spatial resolution of environmental data was $0.0467^{\circ}$ (approx. $4 \times 4 \mathrm{~km}$ ). Average values were calculated for the analysis since SST and CHL were highly correlated among years (Navarro et al. 2016). DO and SSS were compiled from the Bio-Oracle Project (Tyberghein et al., 2012). The depth variable (DEPTH) was obtained from the ETOPO website (see Table S5). Environmental data was transformed to the same resolution as census data using the bilinear resampling technique in ArcMap 10.5.

As species abundance may be similar in neighbouring grid cells due to spatial autocorrelation, we added a spatial predictor set (Legendre and Legendre, 2012) to account for the effect of subjacent spatial structures that were not captured by the environmental factors considered (Navarro et al. 2015). This spatial predictor set was composed of the longitude and latitude of the central point of each grid cell and their interaction terms up to the third order (i.e., $\mathrm{x}+\mathrm{y}+\mathrm{x} 2+\mathrm{xy}+\mathrm{y} 2+\mathrm{x} 3+\mathrm{x} 2-\mathrm{y}+\mathrm{xy} 2+\mathrm{y} 3$, Legendre and Legendre, (2012)).

\section{iii) Modeling procedure}

Following Navarro et al. (2015) and (2016), we built spatial distribution models to estimate the average abundance of considered species across the study area using generalized linear models (GLM) based on environmental and spatial variables (see above). Both the linear and quadratic forms of environmental variables were included in the models to account for potential parabolic trends (i.e. higher and lower values of a variable imply an increase/decrease in abundance compared with intermediate values). Note that testing 
the quadratic form of these variables implies the inclusion of both the variable and its squared term in a model.

Since we were interested in spatial patterns of abundance and because temporal variation across years was low, we used average values of abundance across the ten sampling years as the response variable (Navarro et al., 2016). We fitted a normal error distribution and identity-link functions for this variable (abundance per surveyed area after log-transformation, i.e., number of individuals $\cdot \mathrm{km}^{-2}$ ). We used a multimodel inference approach for model selection. Multi-model inference implies the calculation of the set of models containing all possible combinations of the considered variables (also its linear and quadratic forms). For each model, a probability of being the best model according to Bayesian Information Criteria (BIC) was computed, which strongly penalizes for the number of parameters in models (Burnham and Anderson, 2004). Final models were then calculated as averaged values of models receiving higher support (i.e., those with the 95\% cumulative probability of including the best model) (Burnham and Anderson, 2004). Modelaveraged parameter estimates and their standard errors were calculated, along with variable weights, which indicate the relative importance of each variable in the average model. Final model fit was based on $r$ squared values. The multimodel inference was implemented in R software by the function 'dredge' and 'model.avg' from the 'MuMIm' library.

\section{Systematic prioritization: Marxan approach}

Marxan and Marxan with Zones were used as systematic prioritization softwares (Ball and Possingham, 2000; Watts et al., 2009). Marxan uses simulating annealing as an optimization method to find a cost-efficient reserve network that satisfies a specific conservation target (i.e. minimum set problem). Marxan with Zones is an extension of the traditional Marxan where users can minimize multiple cost layers and can develop more complex planning. Different zones with varying degrees of protection can be designed with specific objectives and restrictions (Watts et al., 2009).

Here, we used the modeled abundance of the five considered species (Fig. 2) as well as the spatial distribution of their potential main threats (Fig. S1) as input data for such analyses. First, since overfishing is considered an important threat to marine biodiversity (McClenachan et al., 2012) and specially for elasmobranchs (Graham et al., 2001; Stein et al., 2018) we considered fishing effort as the main threat 
towards elamosbranch conservation. The Global Fishing Watch database was used to extract fishing activity of trawlers, purse seiners, fixed gear (i.e., pots and traps, set gillnets, and set longlines), and drifting longlines (Kroodsma et al., 2018). Global Fishing Watch is a global online dataset of fishing activity using Automatic Identification System (AIS) data to discern fishing activities from transiting. AIS data is considered a good proxy to track fishing activities in space and time, locally and globally (Kroodsma et al., 2018; Natale et al., 2015; Vespe et al., 2016). Additionaly, other potential threats (SST anomalies, pesticides, fertilizers, ocean pollution, and inorganic pollution, Fig. S1) were obtained from the most recent global threat analysis (Halpern et al., 2015). All threat data was summarized for each planning unit (Fig. S1). The planning unit resolution was designed to have the same resolution as elasmobranch abundance data as recommended by Hermoso and Kennard (2012), obtaining a total of 341 squared grid cells of $0.1^{\circ}$ resolution $\left(95 \pm 1.63 \mathrm{~km}^{2}\right)$.

To assess how accounting for different threats and fishing activity can modify prioritzed areas, we used a hierarchical approach and built different scenarios with increasing level of complexity. First, in Scenario 0 we considered the overlap of core elasmobranch abundance areas; No additional spatial restriction was included in this protected area design strategy. In Scenario 1, area $\left(\mathrm{km}^{2}\right)$ was added as a proxy of the cost to conserve a specific area. In Scenario 2, trawling activity was considered the main threat to the studied elasmobranchs species and consequently used as the cost of protection (Fig. 3, Table 1a). In Scenario 3, all fishing fleets were considered as costs for protection as well as other environmental and anthropogenic potential threats (i.e., SST anomalies, pesticides, fertilizers, ocean pollution, and inorganic pollution; Fig. 3, Table 1a). Finally, Scenario 4, the most complex, was built using Marxan with Zones. It considered three different zones including: no-take zone where all threats were considered as costs; benthic protection zone, where purse seiners, long-liners, and fixed gears were allowed to continue their activities but not bottom trawlers; and available zone where all activities were permitted (Fig. 3, Table 1a). As there is no agreement on the definite percentage of the total abundance of a particular species that should be protected to achieve its persistance, each scenario was run with three different targets.

For the least concern species $30 \%$ (subscenarios a), $40 \%$ (subscenarios b) and 50\% targets (subscenarios c) were considered, while for near threatened species an extra $10 \%$ target was added (Table 1b, Table S1). Since results based on different targets were largely consistent, we only provide those 
referring to the intermediate target (subscenarios b) in subsequent sections (see supplentary material, for additional results). In Marxan with Zones, a 50\% Zone effectiveness for the Benthic protection zone was considered. Half of the global target was placed in the No-take zone and one quarter in the Benthic protection zone. The remaining quarter was not fixed and could be met in each of the zones. To understand the behavior of Zone effectiveness and Zone Target allocation, a sensitivity analysis was carried out (Table S2). Cost-effectiveness (Eq. 1) was calculated for each scenario for the best solution as:

$$
\text { Cost effectiveness }=1-\left(\frac{\text { Cost Planning Units Selected }}{\text { Total Cost }}\right) \quad \text { Eq. } 1
$$

In all scenarios, species penalty factor (SPF) was calibrated with the free software Zonae Cogito (Segan et al., 2011). Calibration was considered a trade-off between SPF and missing values, a common approach to MARXAN problems (Ardron et al., 2010; Segan et al., 2011). The objective of this calibration consists in obtaining solutions where all targets are met (Ardron et al., 2010). We performed 100 runs with $10^{7}$ iterations for each scenario considered. Finally, in order to enable comparison between our different types of cost, we did not preferentially cluster our planning units (Mazor et al. 2014).

\section{i) Overlap with the existing MPA network}

Marxan results were overlapped with the existing MPA network of the western Mediterranean Sea (Fig. 1) to evaluate if the actual MPA network encompasses critical areas for elasmobranch species in the region. We considered MPAs as all spatially designated areas that are declared as protected, including Nationally designated protected areas for the conservation on marine biodiversity (Marine Reserves), Sites of Community Importance (Habitat Directive), and Special Protection Areas for seabirds (Bird Directive). The present network was built with a non-systematic approach, although it was based on scientific evidence of habitat and species importance (MPAtlas, 2016) and includes different levels of protection, from fully protected areas to poorly protected areas Demersal protection is not fully granted in the actual network (Horta e Costa et al., 2016), as information about the presence and abundance of elasmobranch species was not accounted in the current MPAs design.

We calculated the area and the percentage of the proposed conservation sites that are already inside the actual MPA network. MPA polygons were extracted from the World Database on Protected Areas (WDPA; https://www.protectedplanet.net/marine). This is the most up to date, public, and complete source 
of protected areas information worldwide. The database is updated with submission from non-government organizations, national and regional governments, among others, and it is managed by the United Nations Environment World Conservation Monitoring Centre (UNEP-WCMC) with support from the International Union for Conservation of Nature (IUCN) and its World Commission on Protected Areas (WCPA).

\section{RESULTS}

\section{Elasmobranch distributions}

In total, 143 of 169 sampled $0.1^{\circ}$ grid cells were occupied at least once during the study period by one of the study species, 83 by two, 32 by three, 7 by four and none by all of them. $S$. canicula showed the highest abundance values (mean \pm SD: $364 \pm 954 \mathrm{ind} \cdot \mathrm{km}^{-2}$ ), followed by $G$. melastomus $\left(81 \pm 217 \mathrm{ind} \cdot \mathrm{km}^{-}\right.$ $\left.{ }^{2}\right)$, R. asterias $\left(4 \pm 12\right.$ ind $\left.\cdot \mathrm{km}^{-2}\right), T$. Mazor $\left(4 \pm 12 \mathrm{ind} \cdot \mathrm{km}^{-2}\right)$ and $E$. $\operatorname{spinax}\left(3 \pm 12 \mathrm{ind} \cdot \mathrm{km}^{-2}\right)$. The spatial distribution of the five species also differed between them. S. canicula was widely distributed, being detected at least once in $64 \%$ of the study area. In contrast, T. marmorata was detected at least once in $29 \%$, R. asterias and the G. melastomus in $24 \%$ and E. spinax in $12 \%$.

Among environmental variables, the effect of depth on abundance was strong for all species according to their weights in the average model (Fig. S2). The abundance of S. canicula, $R$. asterias and T. marmorata increased in shallow waters. The abundance of G. melastomus and E. spinax increased with deeper waters. An important positive effect of dissolved oxygen concentrations on abundance of these two last species was also detected. In contrast, the strongest effects of salinity were observed for S. canicula and R. asterias. The effect of Chl-a and SST was in general low for all species.

\section{Spatial prioritization}

Priority areas for elasmobranch conservation in the western Mediterranean Sea were encountered in the southern area and in the shelf break of the northern part (Fig. 4-5, Fig. S3-S5). These areas are consistent regardless of the approach/cost used. Increasing the complexity of the spatial planning scenarios by adding threats (Area (Scenario 1) > Trawling (Scenario 2) > All threats (Scenario 3)) did not affect the spatial prioritization of proposed areas (Fig. 4, Fig. S3-S4). In Scenario 4 (Fig. 5, Fig. S5), where zoning is applied 
for spatial prioritization, important areas are also placed in the southern study area and the shelf break in the northern part. This strategy, i.e., including no-take zones and benthic protection zones (partial protection zones) increase cost-efficiency of simpler strategies with only one zone delimited (Table 2 and S3). In all scenarios certain flexibility in planning unit selection is found, nevertheless some areas are highly selected over most of the runs (Figure 4-5) conferring confidence when identifying these sites as important areas for elasmobranch protection.

The area percentage of proposed conservation zones within the present MPA network was on average of $24.04 \%$ with a range between $20.85 \%$ and $30.59 \%$ depending on the scenario (Table S4).

\section{DISCUSSION}

In this study we applied for the first time, a systematic spatial planning approach focused on elasmobranch species in the western and, in general, in the Spanish Mediterranean Sea. Our results can be used to inform proactive area-based protection for the demersal elasmobranch community inhabiting the Mediterranean waters under Spanish jurisdiction, to avoid a further decrease in their conservation status as it has been already documented in several areas of the basin (Aldebert, 1997; Ferretti et al., 2008; Coll, Navarro, \& Palomera, 2013; Pennino et al., 2013; Mendoza, Garrido, \& Bellido, 2014; Dulvy et al., 2016). Indeed, our results highlight that current MPAs included only a small part of ecological relevant areas for the demersal elasmobranch community, probably hampering their potential conservation. In addition, its protection is not granted inside this areas as demersal protection is not always assured (Horta e Costa et al., 2016).

Species investigated here represent the most resilient elasmobranch species of the demersal community on the Mediterranean Sea, probably because their life-history traits (skewed towards the lower values of the fast-slow continuum in elasmobrachs (Quetglas et al., 2016)) made them less vulnerable to human activities than other species with similar habitat and trophic requirements. This make data on these species extremely valuable to set initial conservation priorities for the recovery of the wider demersal elasmobranch community of the western Mediterranean Sea, which has been seriously eroded due to high fishing impact in historic and recent times (Aldebert, 1997; Coll et al., 2010; García et al., 2008; Mendoza et 
al., 2014; Pennino et al., 2013; Rigby and Simpfendorfer, 2015; Simpfendorfer and Kyne, 2009). Nevertheless, it is important to remark that further investigations will be needed for other species, particularly migratory or pelagic sharks and rays, whose ecological requirements might be beyond those encompassed by study species.

Elasmobranch abundance data was found to be more influential in our spatial prioritisation analysis than the cost or approach used. Several studies have highlighted that cost is one of the most influential inputs in systematic conservation planning (Bode et al., 2008; Mazor et al., 2014a). Nevertheless, in the present study, the spatial distribution of different cost layers had no substantial effect on the identified conservation areas, likely due to the high clumping of the studied species in our area. This may explain why even connectivity could be no set as a priority in models developed, although its importance (Beger et al., 2010; Daigle et al., 2020); selected areas were in general highly continuous in space. According to our results, species were mainly concentrated in highly defined marine hotspots within the western Mediterranean Sea, thus to achieve conservation targets we must conserve these areas although some are costly.

We have obtained high irreplaceable sites for conservation although some flexibility is present to accommodate the needs of the different stakeholders. The zoning strategy was the most cost-effective for addressing multiple threats and marine uses in our case study. This means that moving from a single objective approach towards a zoning strategy can enhance the protection of marine biodiversity, while ensuring stakeholders compliance, as the socioeconomic context of multiple maritime activities can be considered (Grantham et al., 2013; Klein et al., 2010; Mazor et al., 2014b). Marine ecosystems are complex socio-ecological systems where durable solutions can be best gained by satisfying both conservation and socioeconomic demands, in this case fisheries. Both factors in potential solutions are considered relevant (Ban et al., 2011; Mazor et al., 2014b; Naidoo et al., 2006), however most research has only focused on the ecological part (e.g., Davidson and Dulvy 2017, Williams et al., 2014). Cost selection in marine spatial planning has important consequences in the selection of protected sites (Mazor et al., 2014a), since considering different costs (e.g. opportunity costs) in different areas may enhance the acceptance of the proposed sites by different stakeholders (Watts et al., 2009) and increase the cost-effectiveness as shown in 
this case study. Our results can contribute towards a more systematic conservation planning when defining marine protected areas in the Mediterranean Sea.

With this study, we contribute to the knowledge on elasmobranch spatial conservation and management planning in the Mediterranean Sea and the ongoing elasmobranch MPA delimitation (Davidson and Dulvy, 2017; Mendoza et al., 2014). According to our results, marine protected sites in our study region could be extended to increase the percentage of Mediterranean waters protected to achieve Aichi 11 target (10\% of the sea protected by 2020) (Amengual and Alvarez-Berastegui, 2018). Here, we have used highquality spatial abundance and threat data, although available data presented some limitations. Future studies should incorporate temporal information on seasonal spatial distribution of these and other elasmobranch species as well as the threats component. Furthermore, elasmobranch movement data (e.g. telemetry studies) or their life stages distributions would be especially informative when creating protected areas for these species (Beger et al., 2010; Daigle et al., 2020) as corridors may need certain protection to maintain the viability of certain species and may show seasonal distributions as observed in other demersal species in the study area (Vilas et al., 2020). Regarding cost data, complementary studies would benefit from adding information about real economic cost value (i.e. Euros) at a finer scale resolution (e.g. Mazor et al., 2014b) instead of using surrogates as in the present study.

According to our results, the actual mosaic of current marine protected measures in our study region of the western Mediterranean Sea does not seem large enough to encompass a sufficient surface of priority areas for demersal elasmobranch conservation. Nevertheless, actual efforts can be enlarged in the northern (i.e. ESZZ16001 - Sistema de cañones submarinos occidentales del Golfo de León), and southern areas (i.e. Espacio Marino de Tabarca-Cabo Palos [ES0000508]) toward off-shore areas to achieve elasmobranch conservation targets and enhancing the marine protection network. It is also important to mention that the current marine protected efforts do not necessarily protect demersal marine communities and as such the current real protection may be much lower (Costa et al., 2016).

Our study illustrates that a pan-Mediterranean analysis using a systematic spatial planning approach of elasmobranch is feasible as this data is obtained through the EU-funded Mediterranean Trawl Survey (MEDITS; Follesa et al. (2019)). Our effort could also be extended to other marine biodiversity components such as finfish, crustaceans and other marine organism to expand the identification of priority areas for 
protection to other compartments of the marine food web. Results from such efforts could be used to complement previous efforts to identify Priority Areas for Conservation of Species at Risk (PACS) in the Mediterranean Sea according to Coll et al. (2015). In this previous study, continental slopes of the northern study areas and the southern part were also identified as important areas for species at risk. Our results can also inform ecosystem models, such as Ecopath with Ecosim, to assess the ecological impact of protecting alternative priority areas of biodiversity concern following established links between systematic planning and ecological modelling tools (Ecospace) (Christensen et al., 2009; Metcalfe et al., 2015).

\section{ACKNOWLEDGEMENTS}

The authors also express their gratitude to all the people who worked in the MEDITS surveys. Thanks to Isabel Afán from the Laboratorio de SIG y Teledetección (LAST) of the Estación Biológica de Doñana CSIC and Francisco Ramírez from ICM-CSIC for their useful discussions and help with spatial data analysis. J. G. partially carried out the analysis of the present study during his research internship at the Centre for Biodiversity and Conservation Science (School of Biological Sciences, University of Queensland) funded by the Spanish Ministry of Economy, Industry, and Competitiveness of the Spanish Government through the predoctoral mobility grant for research internships in foreign $\mathrm{R}+\mathrm{D}$ centers $(\mathrm{EEBB}-$ I-2017-12238). JN was funded by the Spanish National Program Ramón y Cajal (RYC-2015-17809). This study is a contribution to the COST Action 15121 (European Cooperation in Science and Technology; Advancing marine conservation in the European and contiguous seas, MarCons (http://www.marconscost.eu/)) supported by the Horizon 2020 Framework Programme for research and innovation, the project SafeNET (EU-DGMARE MARE/2014/41) and RESNEP (CTM2017-82991-C2-1-R, Spanish Government) MEDITS surveys were funded by the European Maritime and Fisheries Fund (EMFF) of the EU, within the Spanish programme for collection, management and use of data in the fisheries sector and support for scientific advice regarding the Common Fisheries Policy. 


\section{REFERENCES}

Afán, I., Giménez, J., Forero, M.G., Ramírez, F., 2018. An adaptive method for identifying marine areas of high conservation priority. Conserv. Biol. 32, 1436-1447. https://doi.org/10.1111/cobi.13154

Agardy, T., 1997. Marine protected areas and ocean conservation. RE Landes Publishing, Austin, USA.

Aldebert, Y., 1997. Demersal resources of the Gulf of Lions (NW Mediterranean). Impact of exploitation on fish diversity. Vie Milieu 47, 275-284.

Amengual, J., Alvarez-Berastegui, D., 2018. A critical evaluation of the Aichi Biodiversity Target 11 and the Mediterranean MPA network, two years ahead of its deadline. Biol. Conserv. 225, 187-196. https://doi.org/10.1016/j.biocon.2018.06.032

Arcos, J.M., Bécares, J., Villero, D., Brotons, L., Rodríguez, B., Ruiz, A., 2012. Assessing the location and stability of foraging hotspots for pelagic seabirds: An approach to identify marine Important Bird Areas (IBAs) in Spain. Biol. Conserv. 156, 30-42. https://doi.org/10.1016/j.biocon.2011.12.011

Ardron, J.A., Possingham, H.P., Klein, C.J., 2010. Marxan Good Practices Handbook, Version 2. Pacific Marine Analysis and Research Association, Victoria, BC, Canada. 165 pages. www.pacmara.org.

Ball, I.R., Possingham, H.P., 2000. Marxan (v. 1.8.2): Marine Reserve Design Using Spatially Explicit Annealing. A Manual Prepared for The Great Barrier Reef Marine Park Authority. Univ. of Queensland, Brisbane, Australia.

Ban, N.C., Adams, V., Pressey, R.L., Hicks, J., 2011. Promise and problems for estimating management costs of marine protected areas. Conserv. Lett. 4, 241-252. https://doi.org/10.1111/j.1755263X.2011.00171.X

Barría, C., Coll, M., Navarro, J., 2015. Unraveling the ecological role of uncommon and endangered elasmobranchs in the Mediterranean Sea using a comparative approach. Mar. Ecol. Prog. Ser. 539, 225-240. https://doi.org/10.3354/meps11494

Barría, C., Navarro, J., Coll, M., 2018. Feeding habits of four sympatric sharks in two deep-water fishery areas of the western Mediterranean Sea. Deep. Res. Part I Oceanogr. Res. Pap. 142, 34-43. https://doi.org/10.1016/j.dsr.2018.09.010

Beger, M., Linke, S., Watts, M., Game, E., Treml, E., Ball, I., Possingham, H.P., 2010. Incorporating asymmetric connectivity into spatial decision making for conservation. Conserv. Lett. 3, 359-368. 
https://doi.org/10.1111/j.1755-263X.2010.00123.x

Bertrand, J., Gil de Sola Simarro, L., Papakonstantinou, C., Relini, G., Souplet, A., 2000. Contribution on the distribution of elasmobranchs in the Mediterranean (from MEDITS surveys). Biol. Mar. Medit. 7, $1-15$.

Bertrand, J.A., Gil de Sola, L., Papaconstantinou, C., Relini, G., Souplet, A., 2008. The general specifications of the MEDITS surveys. Sci. Mar. 66, 9. https://doi.org/10.3989/scimar.2002.66s29

Bode, M., Wilson, K.A., Brooks, T.M., Turner, W.R., Mittermeier, R.A., McBride, M.F., Underwood, E.C., Possingham, H.P., 2008. Cost-effective global conservation spending is robust to taxonomic group. Proc. Natl. Acad. Sci. U. S. A. 105, 6498-501. https://doi.org/10.1073/pnas.0710705105

Burnham, K.P., Anderson, D.R., 2004. Multimodel Inference. Sociol. Methods Res. 33, 261-304. https://doi.org/10.1177/0049124104268644

Capapé, C., Crouzet, S., Clement, C., Vergne, Y., Guelorget, O., 2007. Diet of the marbled electric ray Torpedo marmorata (Chondrichthyes: Torpedinidae) off the Languedocian coast (Southern France, Northern Mediterranean). Ann. Ser. Hist. Nat. 17, 17-22.

Capapé, C., Desoutter, M., 1990. Torpedinidae, in: Quero, J., Hureau, J., Karrer, C., Post, A., Saldanha, L. (Eds.), Check-List of the Fishes of the Eastern Tropical Atlantic (CLOFETA). JNICT, Lisbon; SEI, Paris; and UNESCO, Paris. Vol. 1. pp. 55-58.

Christensen, V., Ferdaña, Z., Steenbeek, J., 2009. Spatial optimization of protected area placement incorporating ecological, social and economical criteria. Ecol. Modell. 220, 2583-2593. https://doi.org/10.1016/j.ecolmodel.2009.06.029

Clarke, S.C., McAllister, M.K., Milner-Gulland, E.J., Kirkwood, G.P., Michielsens, C.G.J., Agnew, D.J., Pikitch, E.K., Nakano, H., Shivji, M.S., 2006. Global estimates of shark catches using trade records from commercial markets. Ecol. Lett. 9, 1115-1126. https://doi.org/10.1111/j.1461-0248.2006.00968.x Coelho, R., Erzini, K., 2008. Life history of a wide-ranging deepwater lantern shark in the north-east Atlantic, Etmopterus spinax (Chondrichthyes: Etmopteridae), with implications for conservation. J. Fish Biol. 73, 1419-1443. https://doi.org/10.1111/j.1095-8649.2008.02021.x

Coll-Calvo, E., Barría, C., Recasens, L., Navarro, J., 2020. Feeding ecology of a Mediterranean endemic mesopredator living in highly exploited ecosystems. Mar. Environ. Res. 157, 104932. 
https://doi.org/10.1016/j.marenvres.2020.104932

Coll, M., Carreras, M., Ciércoles, C., Cornax, M.-J., Gorelli, G., Morote, E., Sáez, R., 2014. Assessing fishing and marine biodiversity changes using fishers' perceptions: the spanish Mediterranean and gulf of Cadiz case study. PLoS One 9, e85670. https://doi.org/10.1371/journal.pone.0085670

Coll, M., Navarro, J., Palomera, I., 2013. Ecological role, fishing impact, and management options for the recovery of a Mediterranean endemic skate by means of food web models. Biol. Conserv. 157, 108120. https://doi.org/10.1016/j.biocon.2012.06.029

Coll, M., Piroddi, C., Albouy, C., Ben Rais Lasram, F., Cheung, W.W.L., Christensen, V., Karpouzi, V.S., Guilhaumon, F., Mouillot, D., Paleczny, M., Palomares, M.L., Steenbeek, J., Trujillo, P., Watson, R., Pauly, D., 2012. The Mediterranean Sea under siege: Spatial overlap between marine biodiversity, cumulative threats and marine reserves. Glob. Ecol. Biogeogr. 21, 465-480. https://doi.org/10.1111/j.1466-8238.2011.00697.x

Coll, M., Piroddi, C., Steenbeek, J., Kaschner, K., Lasram, F.B.R., Aguzzi, J., Ballesteros, E., Bianchi, C.N., Corbera, J., Dailianis, T., Danovaro, R., Estrada, M., Froglia, C., Galil, B.S., Gasol, J.M., Gertwage, R., Gil, J., Guilhaumon, F., Kesner-Reyes, K., Kitsos, M.S., Koukouras, A., Lampadariou, N., Laxamana, E., de la Cuadra, C.M.L.F., Lotze, H.K., Martin, D., Mouillot, D., Oro, D., Raicevich, S., Rius-Barile, J., Saiz-Salinas, J.I., Vicente, C.S., Somot, S., Templado, J., Turon, X., Vafidis, D., Villanueva, R., Voultsiadou, E., 2010. The biodiversity of the Mediterranean Sea: Estimates, patterns, and threats. PLoS One 5, e11842. https://doi.org/10.1371/journal.pone.0011842

Coll, M., Steenbeek, J., Ben Rais Lasram, F., Mouillot, D., Cury, P., 2015. "Low-hanging fruit” for conservation of marine vertebrate species at risk in the Mediterranean Sea. Glob. Ecol. Biogeogr. 24, 226-239. https://doi.org/10.1111/geb.12250

Daigle, R.M., Metaxas, A., Balbar, A.C., McGowan, J., Treml, E.A., Kuempel, C.D., Possingham, H.P., Beger, M., 2020. Operationalizing ecological connectivity in spatial conservation planning with Marxan Connect. Methods Ecol. Evol. 11, 570-579. https://doi.org/10.1111/2041-210X.13349 Daly, R., Smale, M.J., Singh, S., Anders, D., Shivji, M., Clare, C.A., Lea, J.S.E., Sousa, L.L., Wetherbee, B.M., Fitzpatrick, R., Clarke, C.R., Sheaves, M., Barnett, A., 2018. Refuges and risks: Evaluating the benefits of an expanded MPA network for mobile apex predators. Divers. Distrib. 24, 1217-1230. 
https://doi.org/10.1111/ddi.12758

Davidson, L.N.K., Dulvy, N.K., 2017. Global marine protected areas to prevent extinctions. Nat. Ecol. Evol. 1, 1-6. https://doi.org/10.1038/s41559-016-0040

Dulvy, N., Allen, D., Ralph, G., Walls, R., 2016. The conservation status of Sharks, Rays and in the Mediterranean Sea. IUCN, Malaga, Spain.

Dulvy, N.K., Fowler, S.L., Musick, J.A., Cavanagh, R.D., Kyne, P.M., Harrison, L.R., Carlson, J.K., Davidson, L.N., Fordham, S. V, Francis, M.P., Pollock, C.M., Simpfendorfer, C.A., Burgess, G.H., Carpenter, K.E., Compagno, L.J., Ebert, D.A., Gibson, C., Heupel, M.R., Livingstone, S.R., Sanciangco, J.C., Stevens, J.D., Valenti, S., White, W.T., 2014. Extinction risk and conservation of the world's sharks and rays. Elife 3, e00590. https://doi.org/10.7554/eLife.00590

Estrada, M., 1996. Primary production in the northwestern Mediterranean. Sci. Mar. 60, 55-64.

EU, 2009. Communication from the Commission to the European Parliament and the Council on a European Community action plan for the conservation and management of sharks.

Evans, P.G.H., 2018. Marine Protected Areas and marine spatial planning for the benefit of marine mammals. J. Mar. Biol. Assoc. UK 98, 973-976. https://doi.org/10.1017/S0025315418000334

FAO, 2018. The State of Mediterranean and Black Sea Fisheries. General Fisheries Commission for the Mediterranean. Rome.

Ferretti, F., Myers, R.A., Serena, F., Lotze, H.K., 2008. Loss of Large Predatory Sharks from the Mediterranean Sea. Conserv. Biol. 22, 952-964. https://doi.org/10.1111/j.1523-1739.2008.00938.x

Ferretti, F., Worm, B., Britten, G.L., Heithaus, M.R., Lotze, H.K., 2010. Patterns and ecosystem consequences of shark declines in the ocean. Ecol. Lett. 13, 1055-1071. https://doi.org/10.1111/j.14610248.2010.01489.x

Follesa, M.C., Marongiu, M.F., Zupa, W., Bellodi, A., Cau, Alessandro, Cannas, R., Colloca, F., Djurovic, M., Isajlovic, I., Jadaud, A., Manfredi, C., Mulas, A., Peristeraki, P., Porcu, C., Ramirez-Amaro, S., Jiménez, F.S., Serena, F., Sion, L., Thasitis, I., Cau, Angelo, Carbonara, P., 2019. Spatial variability of chondrichthyes in the northern Mediterranean. Sci. Mar. 83, 81-100. https://doi.org/10.3989/scimar.04998.23A

Frisk, M.G., Miller, T.J., Dulvy, N.K., 2005. Life histories and vulnerability to exploitation of 
elasmobranchs: Inferences from elasticity, perturbation and phylogenetic analyses. J. Northwest Atl. Fish. Sci. 35, 27-45. https://doi.org/10.2960/J.v35.m514

Gallagher, A.J., Kyne, P.M., Hammerschlag, N., 2012. Ecological risk assessment and its application to elasmobranch conservation and management. J. Fish Biol. 80, 1727-1748. https://doi.org/10.1111/j.1095-8649.2012.03235.x

García, V.B., Lucifora, L.O., Myers, R.A., 2008. The importance of habitat and life history to extinction risk in sharks, skates, rays and chimaeras. Proc. R. Soc. B Biol. Sci. 275, 83-89. https://doi.org/10.1098/rspb.2007.1295

Gormley, A.M., Slooten, E., Dawson, S., Barker, R.J., Rayment, W., du Fresne, S., Bräger, S., 2012. First evidence that marine protected areas can work for marine mammals. J. Appl. Ecol. 49, 474-480. https://doi.org/10.1111/j.1365-2664.2012.02121.x

Gouraguine, A., Hidalgo, M., Moranta, J., Bailey, D.M., Ordines, F., Guijarro, B., Valls, M., Barberá, C., De Mesa, A., Mesa, A. De, 2011. Elasmobranch spatial segregation in the western Mediterranean. Sci. Mar. 75, 653-664. https://doi.org/10.3989/scimar.2011.75n4653

Graham, K.J., Andrew, N.L., Hodgson, K.E., 2001. Changes in relative abundance of sharks and rays on Australian South East Fishery trawl grounds after twenty years of fishing. Mar. Freshw. Res. 52, 11251132. https://doi.org/10.1111/j.1550-7408.2011.00547.x

Grantham, H.S., Agostini, V.N., Wilson, J., Mangubhai, S., Hidayat, N., Muljadi, A., Muhajir, Rotinsulu, C., Mongdong, M., Beck, M.W., Possingham, H.P., 2013. A comparison of zoning analyses to inform the planning of a marine protected area network in Raja Ampat, Indonesia. Mar. Policy 38, 184-194. https://doi.org/10.1016/j.marpol.2012.05.035

Halpern, B.S., Frazier, M., Potapenko, J., Casey, K.S., Koenig, K., Longo, C., Lowndes, J.S., Rockwood, R.C., Selig, E.R., Selkoe, K.A., Walbridge, S., 2015. Spatial and temporal changes in cumulative human impacts on the world's ocean. Nat. Commun. 6, 7615. https://doi.org/10.1038/ncomms8615

Hermoso, V., Kennard, M.J., 2012. Uncertainty in coarse conservation assessments hinders the efficient achievement of conservation goals. Biol. Conserv. 147, 52-59. https://doi.org/10.1016/j.biocon.2012.01.020

Hooker, S., Cañadas, A., Hyrenbach, K., Corrigan, C., Polovina, J., Reeves, R., 2011. Making protected area 
networks effective for marine top predators. Endanger. Species Res. 13, $203-218$.

https://doi.org/10.3354/esr00322

Hooker, S.K., Gerber, L.R., 2004. Marine Reserves as a Tool for Ecosystem-Based Management: The Potential Importance of Megafauna. Bioscience 54, 27-39.

Horta e Costa, B., Claudet, J., Franco, G., Erzini, K., Caro, A., Gonçalves, E.J., 2016. A regulation-based classification system for Marine Protected Areas (MPAs). Mar. Policy 72, 192-198. https://doi.org/10.1016/j.marpol.2016.06.021

Hureau, J.C., Bauchot, M.L., Tortonese, E., Nielsen, J., 1984. Fishes of the North-eastern Atlantic and the Mediterranean. Vol. 1. Unesco. Unesco.

IUCN, 2019. The IUCN Red List of Threatened Species. [WWW Document].

Jackson, J.B., Kirby, M.X., Berger, W.H., Bjorndal, K.A., Botsford, L.W., Bourque, B.J., Bradbury, R.H., Cooke, R., Erlandson, J., Estes, J.A., Hughes, T.P., Kidwell, S., Lange, C.B., Lenihan, H.S., Pandolfi, J.M., Peterson, C.H., Steneck, R.S., Tegner, M.J., Warner, R.R., 2001. Historical overfishing and the recent collapse of coastal ecosystems. Science (80-. ). 293, 629-37. https://doi.org/10.1126/science.1059199

Katsanevakis, S., Mackelworth, P., Coll, M., Fraschetti, S., Ma, V., Giakoumi, S., Jones, P.J.S., Levin, N., Albano, P.G., Badalamenti, F., Ruth, E., Claudet, J., Culibrk, D., Anna, G.D., Deidun, A., Garcíacharton, J.A., Goldsborough, D., Holcer, D., Jimenez, C., Kark, S., Sørensen, T.K., Lazar, B., Martin, G., Mazaris, A., Pipitone, C., Portman, M., Pranovi, F., Rilov, G., Smith, R.J., Stelzenmüller, V., Vogiatzakis, I.N., Winters, G., 2017. Advancing marine conservation in European and contiguous seas with the MarCons Action. Res. Ideas Outcomes 3, e11884. https://doi.org/10.3897/rio.3.e11884 Katsanevakis, S., Maravelias, C.D., Damalas, D., Karageorgis, A.P., Tsitsika, E. V., Anagnostou, C., Papaconstantinou, C., 2009. Spatiotemporal distribution and habitat use of commercial demersal species in the eastern Mediterranean Sea. Fish. Oceanogr. 18, 439-457. https://doi.org/10.1111/j.13652419.2009.00523.x

Kelleher, G., 1999. Guidelines for marine protected areas. Best Practice Protected Area IUCN, Gland, Switzerland and Cambridge, UK.

Klein, C.J., Steinback, C., Watts, M., Scholz, A.J., Possingham, H.P., 2010. Spatial marine zoning for 
fisheries and conservation. Front. Ecol. Environ. 8, 349-353. https://doi.org/10.1890/090047

Korkmaz, S., Goksuluk, D., Zararsiz, G., 2014. MVN: An R Package for Assessing Multivariate Normality.

R J. 6, 151-162. https://doi.org/10.1136/bmj.s4-1.148.879

Korpinen, S., Andersen, J.H., 2016. A Global Review of Cumulative Pressure and Impact Assessments in Marine Environments. Front. Mar. Sci. 3, 153. https://doi.org/10.3389/fmars.2016.00153

Kroodsma, D.A., Mayorga, J., Hochberg, T., Miller, N.A., Boerder, K., Ferretti, F., Wilson, A., Bergman, B., White, T.D., Block, B.A., Woods, P., Sullivan, B., Costello, C., Worm, B., 2018. Tracking the global footprint of fisheries. Science (80-. ). 359, 904-908.

Legendre, P., Legendre, L.F., 2012. Numerical ecology, 3rd ed. Elsevier.

Malak, D.A., Livingstone, S.R., Pollard, D., Polidoro, B.A., Cuttelod, A., Bariche, M., Bilecenoglu, M., Carpenter, K.E., Collette, B.B., Francour, P., Goren, M., Kara, M.H., Papaconstantinou, C., Tunesi, L., 2011. Overview of the Conservation Status of the Marine Fishes of the Mediterranean Sea. Gland, Switzerland and Malaga, Spain.

Mazor, T., Giakoumi, S., Kark, S., Possingham, H.P., 2014a. Large-scale conservation planning in a multinational marine environment: Cost matters. Ecol. Appl. 24, 1115-1130. https://doi.org/10.1890/13-1249.1

Mazor, T., Possingham, H.P., Edelist, D., Brokovich, E., Kark, S., 2014b. The crowded sea: Incorporating multiple marine activities in conservation plans can significantly alter spatial priorities. PLoS One 9, e104489. https://doi.org/10.1371/journal.pone.0104489

McClenachan, L., Cooper, A.B., Carpenter, K.E., Dulvy, N.K., 2012. Extinction risk and bottlenecks in the conservation of charismatic marine species. Conserv. Lett. 5, 73-80. https://doi.org/10.1111/j.1755263X.2011.00206.X

Mendoza, M., Garrido, D., Bellido, J.M., 2014. Factors affecting the fishing impact on cartilaginous fishes in southeastern Spain (western Mediterranean Sea). Sci. Mar. 78, 67-76. https://doi.org/10.3989/scimar.04025.21a

Metcalfe, K., Vaz, S., Engelhard, G.H., Villanueva, M.C., Smith, R.J., Mackinson, S., 2015. Evaluating conservation and fisheries management strategies by linking spatial prioritization software and ecosystem and fisheries modelling tools. J. Appl. Ecol. 52, 665-674. https://doi.org/10.1111/1365- 
2664.12404

Micheli, F., Halpern, B.S., Walbridge, S., Ciriaco, S., Ferretti, F., Fraschetti, S., Lewison, R., Nykjaer, L., Rosenberg, A.A., 2013a. Cumulative human impacts on Mediterranean and Black Sea marine ecosystems: Assessing current pressures and opportunities. PLoS One 8, e79889. https://doi.org/10.1371/journal.pone.0079889

Micheli, F., Levin, N., Giakoumi, S., Katsanevakis, S., Abdulla, A., Coll, M., Fraschetti, S., Kark, S., Koutsoubas, D., Mackelworth, P., Maiorano, L., Possingham, H.P., 2013b. Setting Priorities for Regional Conservation Planning in the Mediterranean Sea. PLoS One 8, e59038. https://doi.org/10.1371/journal.pone.0059038

MPAtlas, 2016. Marine Protected Atlas (www.mpatlas.org) [WWW Document]. Mar. Conserv. Inst. Myers, R.A., Baum, J.K., Shepherd, T.D., Powers, S.P., Peterson, C.H., 2007. Cascading Effects of the Loss of Apex Predatory Sharks from a Coastal Ocean. Science (80-. ). 315, 1846-1850.

Naidoo, R., Balmford, A., Ferraro, P.J., Polasky, S., Ricketts, T.H., Rouget, M., 2006. Integrating economic costs into conservation planning. Trends Ecol. Evol. 21, 681-687. https://doi.org/10.1016/j.tree.2006.10.003

Natale, F., Gibin, M., Alessandrini, A., Vespe, M., Paulrud, A., 2015. Mapping Fishing Effort through AIS Data. PLoS One 10, e0130746. https://doi.org/10.1371/journal.pone.0130746

Navarro, J., Cardador, L., Fernández, Á.M., Bellido, J.M., Coll, M., 2016. Differences in the relative roles of environment, prey availability and human activity in the spatial distribution of two marine mesopredators living in highly exploited ecosystems. J. Biogeogr. 43, n/a-n/a. https://doi.org/10.1111/jbi.12648

Navarro, J., Coll, M., Cardador, L., Fern??ndez, ??ngel M., Bellido, J.M.J.M., Fernández, Á.M., Bellido, J.M.J.M., 2015. The relative roles of the environment, human activities and spatial factors in the spatial distribution of marine biodiversity in the Western Mediterranean Sea. Prog. Oceanogr. 131, 126-137. https://doi.org/10.1016/j.pocean.2014.12.004

Navarro, J., Coll, M., Preminger, M., Palomera, I., 2013. Feeding ecology and trophic position of a Mediterranean endemic ray: Consistency between sexes, maturity stages and seasons. Environ. Biol. Fishes 96, 1315-1328. https://doi.org/10.1007/s10641-013-0109-7 
Papaconstantinou, G., Farrugio, H., 2000. Fisheries in the Mediterranean. Mediterr. Mar. Sci. 1, 5-18. https://doi.org/10.12681/mms.2

Pennino, M.G., Muñoz, F., Conesa, D., López-Qúlez, A., Bellido, J.M., 2013. Modeling sensitive elasmobranch habitats. J. Sea Res. 83, 209-218. https://doi.org/10.1016/j.seares.2013.03.005

Pomeroy, R.S., Watson, L.M., Parks, J.E., Cid, G.A., 2005. How is your MPA doing? A methodology for evaluating the management effectiveness of marine protected areas. Ocean Coast. Manag. 48, 485-502. https://doi.org/10.1016/J.OCECOAMAN.2005.05.004

Quetglas, A., Rueda, L., Alvarez-Berastegui, D., Guijarro, B., Massutí, E., 2016. Contrasting responses to harvesting and environmental drivers of fast and slow life history species. PLoS One 11, e0148770. https://doi.org/10.1371/journal.pone.0148770

Ramírez, F., Coll, M., Navarro, J., Bustamante, J., Green, A.J., 2018. Spatial congruence between multiple stressors in the Mediterranean Sea may reduce its resilience to climate impacts. Sci. Rep. 8, 14871. https://doi.org/10.1038/s41598-018-33237-w

Rigby, C., Simpfendorfer, C.A., 2015. Patterns in life history traits of deep-water chondrichthyans. Deep. Res. Part II Top. Stud. Oceanogr. 115, 30-40. https://doi.org/10.1016/j.dsr2.2013.09.004

Ronconi, R. a., Lascelles, B.G., Langham, G.M., Reid, J.B., Oro, D., 2012. The role of seabirds in Marine Protected Area identification, delineation, and monitoring: Introduction and synthesis. Biol. Conserv. 156, 1-4. https://doi.org/10.1016/j.biocon.2012.02.016

Segan, D.B., Game, E.T., Watts, M.E., Stewart, R.R., Possingham, H.P., 2011. An interoperable decision support tool for conservation planning. Environ. Model. Softw. 26, 1434-1441. https://doi.org/10.1016/j.envsoft.2011.08.002

Serena, F., Abella, A., Walls, R., Dulvy, N., 2015. Raja asterias. The IUCN Red List of Threatened Species 2015.

Sergio, F., Caro, T., Brown, D., Clucas, B., Hunter, J., Ketchum, J., Mchugh, K., Hiraldo, F., 2008. Top Predators as Conservation Tools: Ecological Rationale, Assumptions, and Efficacy. Annu. Rev. Ecol. Evol. Syst. 39, 1-19. https://doi.org/10.1146/annurev.ecolsys.39.110707.173545

Simpfendorfer, C.A., Kyne, P.M., 2009. Limited potential to recover from overfishing raises concerns for deep-sea sharks, rays and chimaeras. Environ. Conserv. 36, 97-103. 
https://doi.org/10.1017/S0376892909990191

Stein, R.W., Mull, C.G., Kuhn, T.S., Aschliman, N.C., Davidson, L.N.K., Joy, J.B., Smith, G.J., Dulvy, N.K., Mooers, A.O., 2018. Global priorities for conserving the evolutionary history of sharks, rays and chimaeras. Nat. Ecol. Evol. 1-11. https://doi.org/10.1038/s41559-017-0448-4

Stevens, J., 2000. The effects of fishing on sharks, rays, and chimaeras (chondrichthyans), and the implications for marine ecosystems. ICES J. Mar. Sci. 57, 476-494. https://doi.org/10.1006/jmsc.2000.0724

Valls, M., Quetglas, A., Ordines, F., Moranta, J., Moranta, J., 2011. Feeding ecology of demersal elasmobranchs from the shelf and slope off the Balearic Sea (western Mediterranean). Sci. Mar. 75, 633-639. https://doi.org/10.3989/scimar.2011.75n4633

Venter, O., Sanderson, E.W., Magrach, A., Allan, J.R., Beher, J., Jones, K.R., Possingham, H.P., Laurance, W.F., Wood, P., Fekete, B.M., Levy, M.A., Watson, J.E.M., 2016. Sixteen years of change in the global terrestrial human footprint and implications for biodiversity conservation. Nat. Commun. 7, 1-11. https://doi.org/10.1038/ncomms 12558

Vespe, M., Gibin, M., Alessandrini, A., Natale, F., Mazzarella, F., Osio, G.C., 2016. Mapping EU fishing activities using ship tracking data. J. Maps 12, 520-525.

Vilas, D., Pennino, M.G., Bellido, J.M., Navarro, J., Palomera, I., Coll, M., 2020. Seasonality of spatial patterns of abundance, biomass and biodiversity in a demersal community of the NW Mediterranean Sea. ICES J. Mar. Sci. 77, 567-580.

Watts, M.E., Ball, I.R., Stewart, R.S., Klein, C.J., Wilson, K., Steinback, C., Lourival, R., Kircher, L., Possingham, H.P., 2009. Marxan with Zones: Software for optimal conservation based land- and seause zoning. Environ. Model. Softw. 24, 1513-1521. https://doi.org/10.1016/j.envsoft.2009.06.005

Watts, M.E., Stewart, R.R., Martin, T.G., Klein, C.J., Carwardine, J., Possingham, H.P., 2017. Systematic Conservation Planning with Marxan, in: Learning Landscape Ecology. pp. 211-227.

Williams, R., Grand, J., Hooker, S.K., Buckland, S.T., Reeves, R.R., Rojas-Bracho, L., Sandilands, D., Kaschner, K., 2014. Prioritizing global marine mammal habitats using density maps in place of range maps. Ecography (Cop.). 37, 212-220. https://doi.org/10.1111/j.1600-0587.2013.00479.x 
Table 1: Scenario (a) and subscenarios (b) summary. *All threats: Trawling, purse seine, difting long-lines, and fixed gear fishing activity, SST anomalies, pesticides, fertilizers, ocean pollution, and inorganic pollution.

\begin{tabular}{|c|c|c|c|}
\hline a) & Scenario & Analysis & Cost used \\
\hline & 0 & Spatial overlap & No cost \\
\hline & 1 & Marxan & Area \\
\hline & 2 & Marxan & Trawling activity \\
\hline & 3 & Marxan & All threats* \\
\hline & 4 & Marxan with Zones & > No-take Zone: All threats \\
\hline & & & $\begin{array}{l}>\text { Benthic Protection Zone: All threats except } \\
\text { purse seiners, long liners, and fixed gears }\end{array}$ \\
\hline \multirow[t]{4}{*}{ b) } & Subscenario & $\begin{array}{l}\text { Protection least } \\
\text { concern species }\end{array}$ & $\begin{array}{l}\text { Protection near } \\
\text { threatened species }\end{array}$ \\
\hline & a & $30 \%$ protection & $40 \%$ protection \\
\hline & $b$ & $40 \%$ protection & $50 \%$ protection \\
\hline & c & $50 \%$ protection & $60 \%$ protection \\
\hline
\end{tabular}




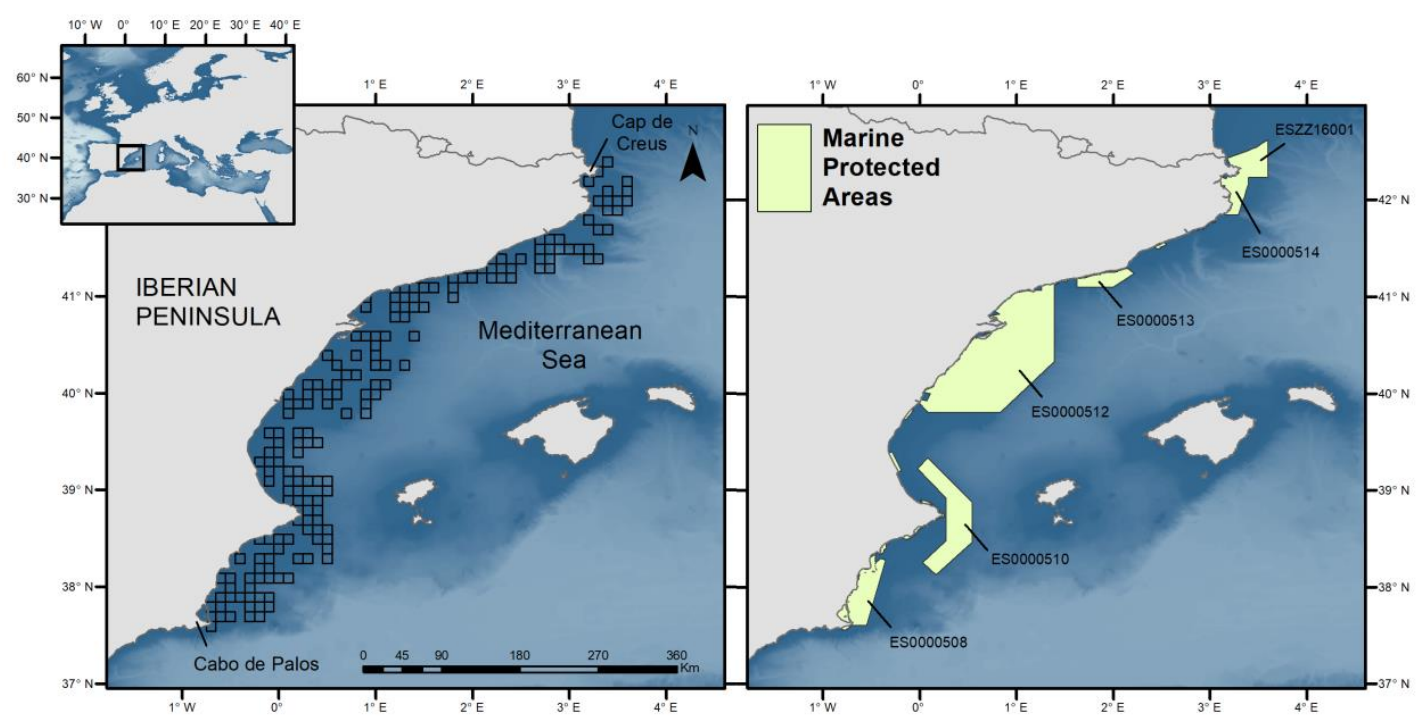

Figure 1: Distribution of the sampled fishing grids in the Western Mediterranean Sea and MPAs of the research area. ESZZ16001: "Sistema de cañones submarinos occidentales del Golfo de León", ES0000514: "Espacio marino de I'Empordà", ES0000513: "Espacio marino del Baix Llobregat-Garraf", ES0000512: "Espacio marino del Delta de I'Ebre - Illes Columbretes", ES0000510: "Plataforma-talud marinos del Cabo de la Nao", ES0000508: "Espacio marino de Tabarca-Cabo de Palos".

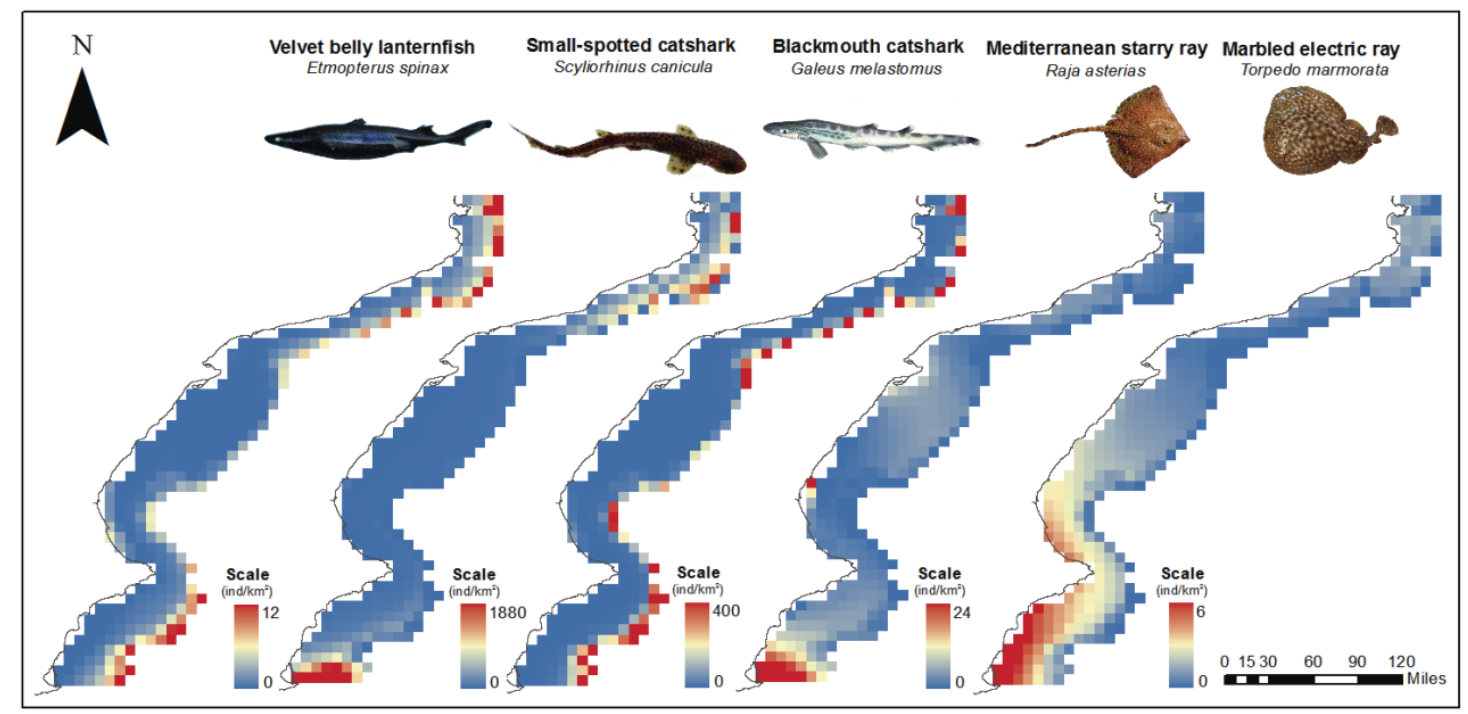

Figure 2: Elasmobranch abundance in the western Mediterranean Sea. Each species has a different abundance scale (ind $/ \mathrm{km}^{2}$ ). 


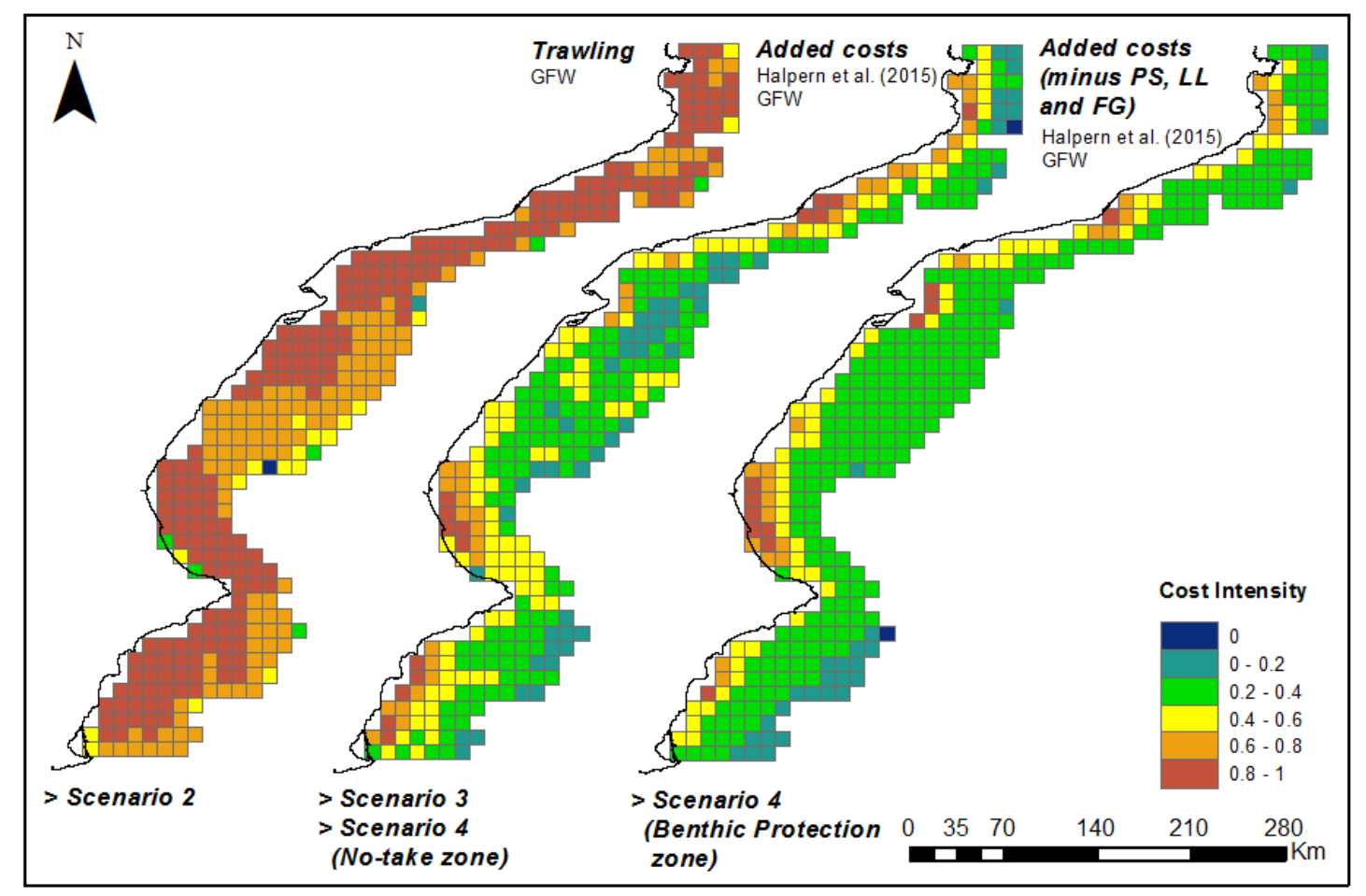

Figure 3: Cost layers used in the Marxan analyses. GFW: Global Fishing Watch, PS: Purse seiners, LL: Long-liners, and FG: Fixed gears.

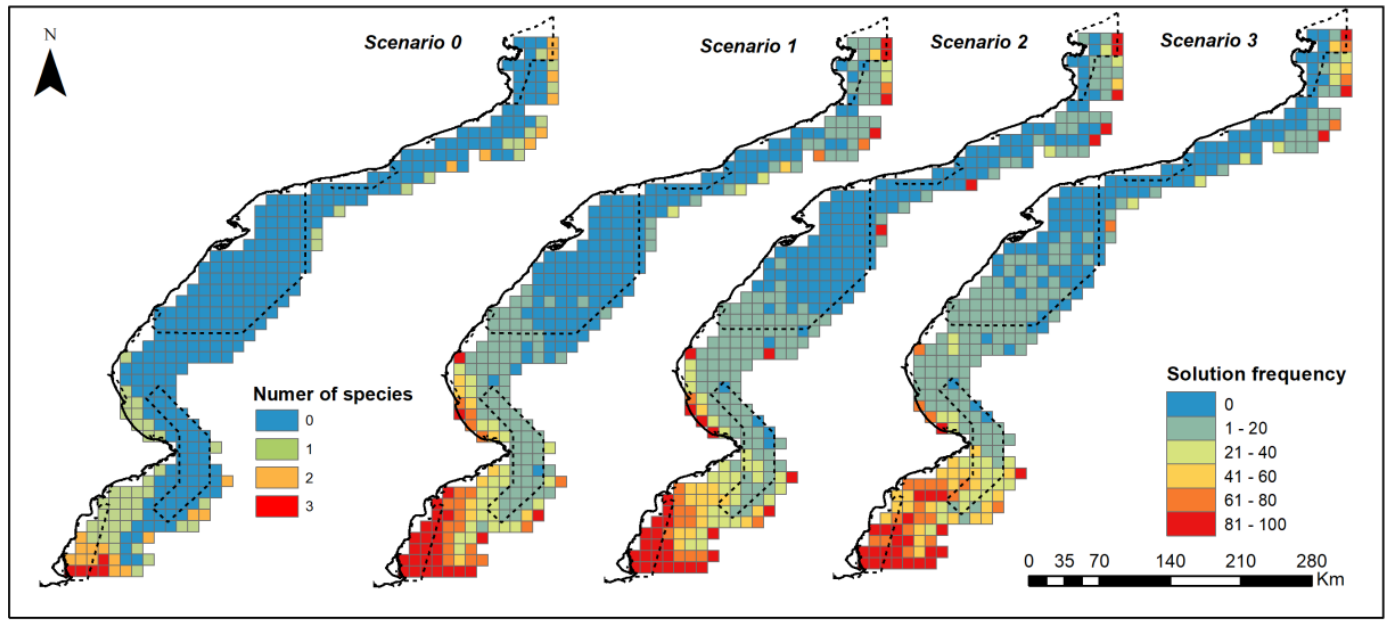

Figure 4: Overlap of core areas for each species depicting high abundance areas (Scenario 0 ) and solution frequencies of Marxan analyses (Scenario 1-3). Scenario 1: Area as cost; Scenario 2: Trawling activity as cost; Scenario 3: All costs. MPAs are overlay with a dotted line. 


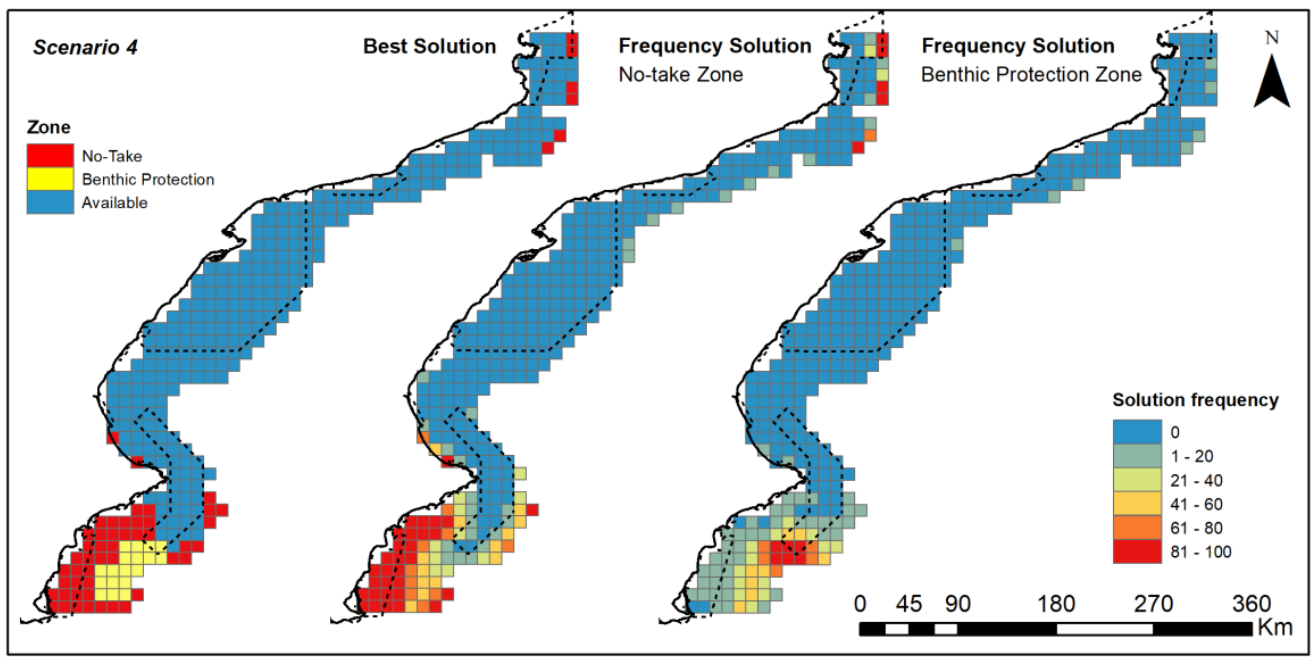

Figure 5: Best solution and solution frequencies of Marxan with zones (Scenario 4) for the no-take and benthic protection zone. MPAs are overlay with a dotted line. 
Marine protected areas for demersal elasmobranchs in highly exploited

\section{Mediterranean ecosystems}

Joan Giménez, Laura Cardador, Tessa Mazor, Salit Kark, José Maria Bellido, Marta Coll and Joan Navarro 


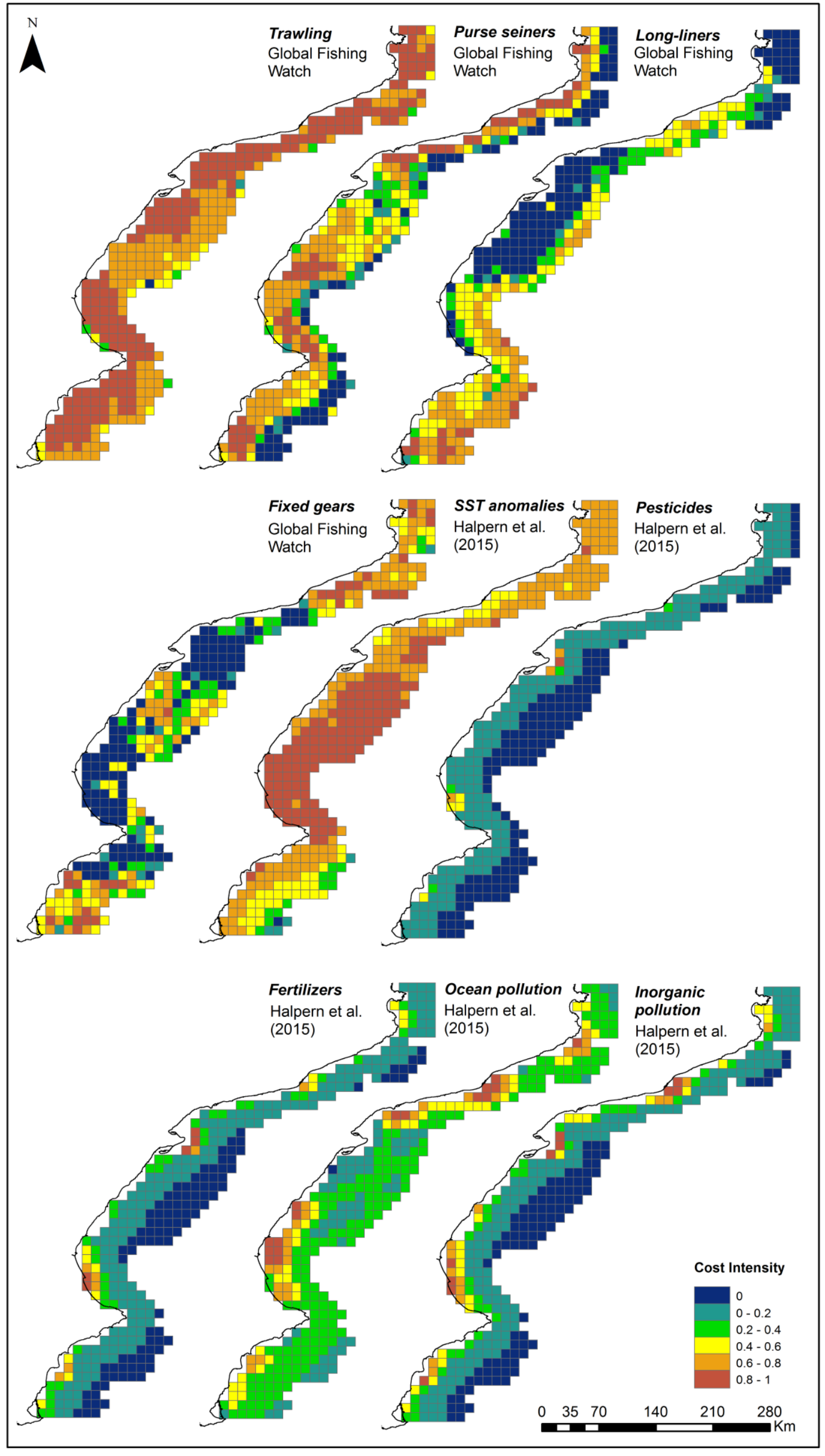

Figure S1: Main threats for elasmobranch species in the Western Mediterranean Sea based on Halpern et al. (2015) and Global Fishing Watch. 

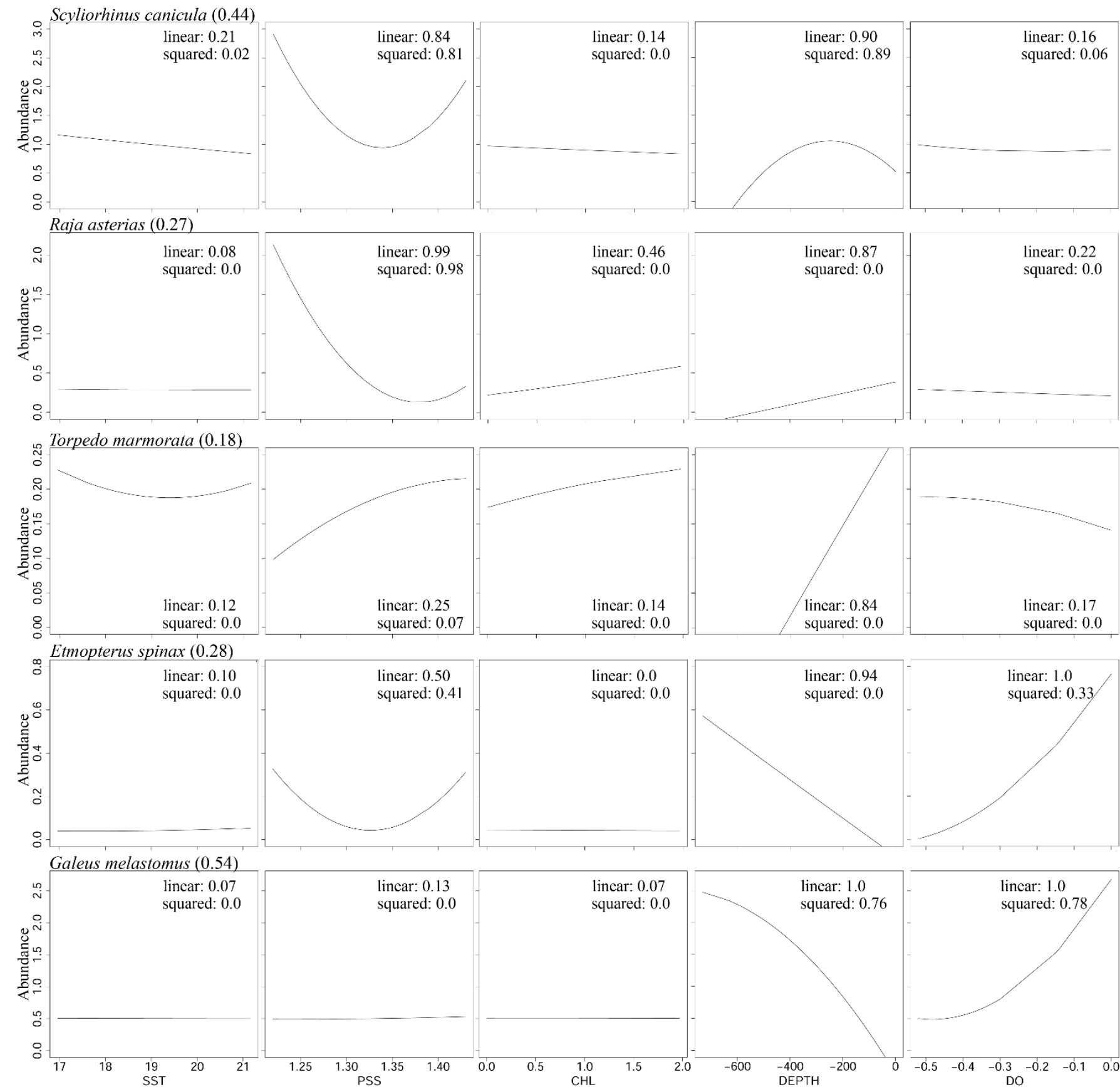

Figure S2: Partial response curves showing the relationships between species abundance and environmental variables. Note that abundance values represent abundance per surveyed area after log-transformation, i.e., number of individuals $/ \mathrm{km}^{2}$. Weights for the linear and squared forms of each variable, which indicate the relative importance of each variable in the average model, are shown. Model fit $\left(R^{2}\right)$ for each species is shown in parenthesis. 


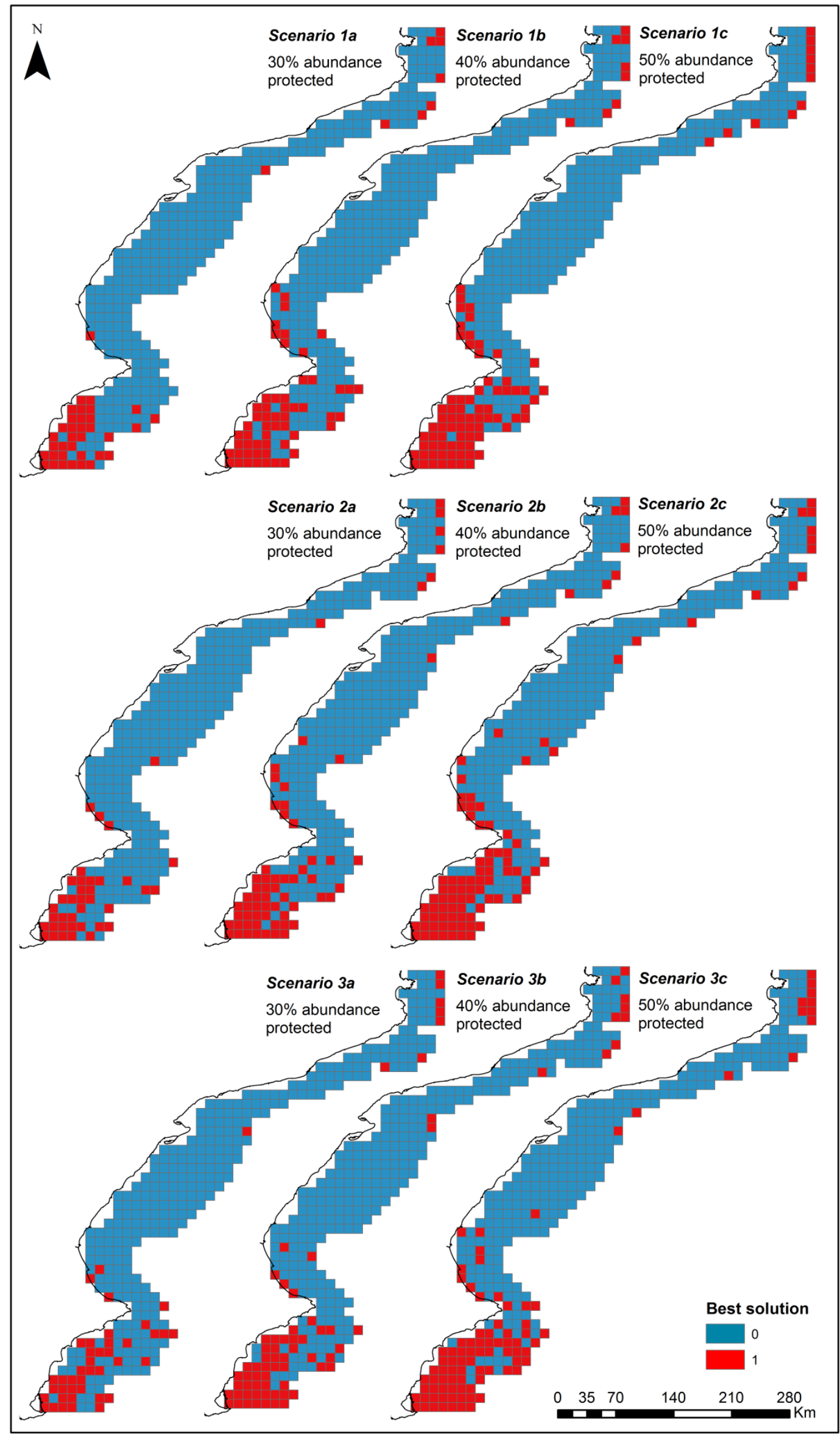

Figure S3: Best solutions of Marxan analyses for each scenario (1-3) and each target (a-c) 


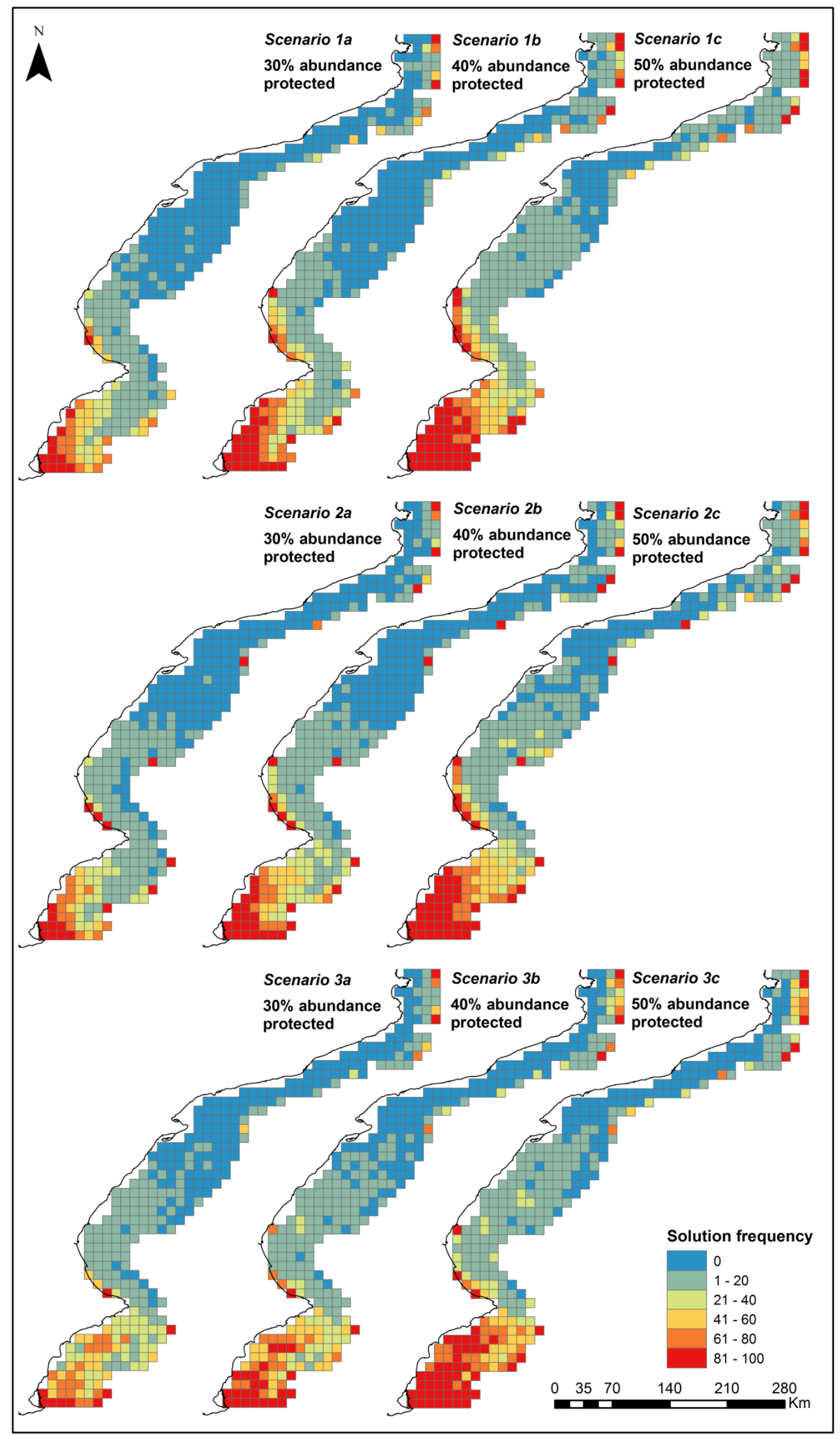

Figure S4: Solution frequencies of Marxan analyses for each scenario (1-3) and each target (a-c). 


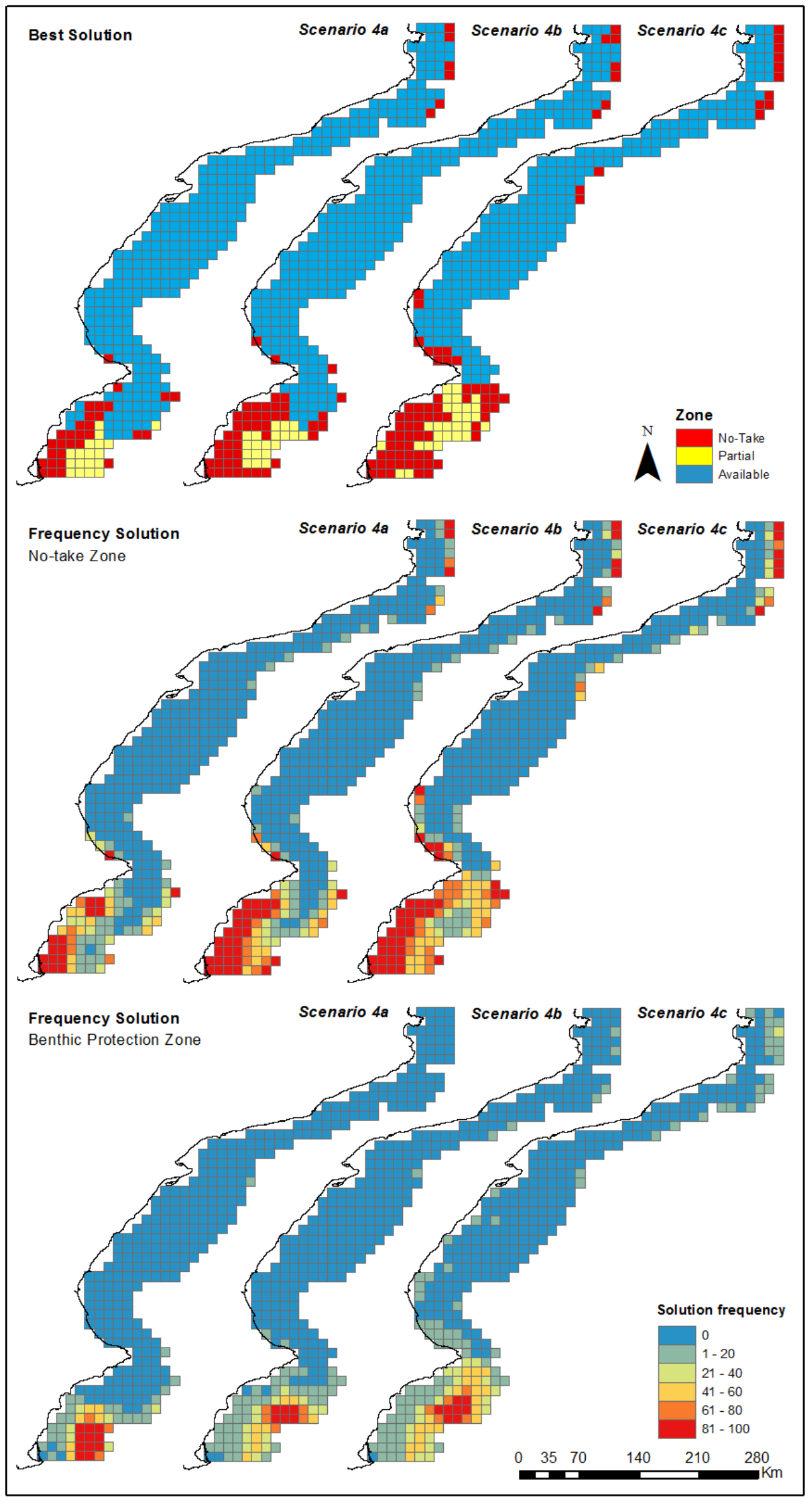

Figure S5: Best solution and solution frequencies of Marxan with zones for the no-take and benthic protection zone. 
Table S1: IUCN category, Fish Base vulnerability index and Zone effectiveness (100 - Fish Base vulnerability Index) for each studied species.

\begin{tabular}{llccc}
\multicolumn{1}{c}{ Scientific name } & \multicolumn{1}{c}{ Common name } & IUCN category & Fish Base Vulnerability & Zone effectiveness \\
\hline Scyliorhinus canicula & Small spotted catshark & Least Concern (LC) & High (62 of 100) & $38 \%$ \\
Galeus melastomus & Blachmouth catshark & Least Concern (LC) & High (57 of 100) & $43 \%$ \\
Etmopterus spinax & Velvet belly lanternshark & Least Concern (LC) & Moderate to high (47 of 100) & $53 \%$ \\
Raja asterias & Mediterranean starry ray & Near Threatened (NT) & Moderate to high (50 of 100) & $50 \%$ \\
Torpedo marmorata & Marbled electric ray & Least Concern (LC) & High to very high (69 of 100) & $31 \%$ \\
\hline \hline
\end{tabular}

Table S2: Summary of the sensitivity analysis to understand the behavior of Zone Effectiveness and Zone Target contribution.

Zone effectiveness: For the "No-take zone" a zone effectiveness of $100 \%$ protection for each species was considered while for the "Benthic protection zone" we used a 50\% zone effectiveness. Also we tested the effect on using species vulnerability values from expert surveys extracted from published literature (http://www.fishbase.org/; as done in Cheung et al. (2005) and Mazor et al. (2014)) as zone effectiveness, as well as using a higher zone effectiveness of $75 \%$ to evaluate the influence on changing this parameter. Cost effectiveness was very similar between options considered.

\begin{tabular}{|l|c|c|c|}
\hline Zone Effectiveness & Fish Base & $\mathbf{5 0 \%}$ & $\mathbf{7 5 \%}$ \\
\hline Cost Effectiveness & 0.80 & 0.81 & 0.84 \\
\hline
\end{tabular}


Zone Target allocation: In the final analysis the global target (0.3) was allocated as half of the global target (0.15) in the "No-take zone" and one quarter $(0.075)$ in the "Benthic protection zone". The remaining quarter was not fixed and could be met in each of the zones (Option b). Other two zone target allocations were assessed to evaluate the influence on changing this parameter (Option a and c). Cost effectiveness was the same in all the options.

\begin{tabular}{|l|c|c|c|c|c|c|c|c|c|}
\cline { 2 - 9 } \multicolumn{1}{c|}{} & \multicolumn{3}{c|}{ a) } & \multicolumn{3}{c|}{ b) } & \multicolumn{3}{c|}{ c) } \\
\cline { 2 - 9 } & $\begin{array}{c}\text { No take } \\
\text { zone }\end{array}$ & $\begin{array}{c}\text { Benthic } \\
\text { protection } \\
\text { zone }\end{array}$ & $\begin{array}{c}\text { Both } \\
\text { zones }\end{array}$ & $\begin{array}{c}\text { No take } \\
\text { zones }\end{array}$ & $\begin{array}{c}\text { Benthic } \\
\text { protection } \\
\text { zones }\end{array}$ & $\begin{array}{c}\text { Both } \\
\text { zones }\end{array}$ & $\begin{array}{c}\text { No take } \\
\text { zones }\end{array}$ & $\begin{array}{c}\text { Benthic } \\
\text { protection } \\
\text { area }\end{array}$ & $\begin{array}{c}\text { Both } \\
\text { zones }\end{array}$ \\
\hline $\begin{array}{l}\text { Zone Target } \\
\text { contibution }\end{array}$ & $\mathbf{0 . 1}$ & $\mathbf{0 . 0 5}$ & $\mathbf{0 . 1 5}$ & $\mathbf{0 . 1 5}$ & $\mathbf{0 . 0 7 5}$ & $\mathbf{0 . 0 7 5}$ & $\mathbf{0 . 2}$ & $\mathbf{0 . 1}$ & - \\
\hline $\begin{array}{l}\text { Cost } \\
\text { Effectiveness }\end{array}$ & \multicolumn{3}{c}{0.81} & & 0.81 & & & 0.81 \\
\hline
\end{tabular}


Table S3: Summary of each scenario considered. PU: Planning Units and Cost Effectiveness. The best solution and the mean of all runs are calculated for each scenario.

\begin{tabular}{|c|c|c|c|}
\hline Scenario & & Area & $\begin{array}{c}\text { Cost } \\
\text { Effectiveness }\end{array}$ \\
\hline $1 a$ & & 4156.24 & 0.87 \\
\hline $2 a$ & & 4253.19 & 0.89 \\
\hline $3 a$ & & 4636.77 & 0.86 \\
\hline $4 a$ & No-take & 3289.44 & 0.89 \\
\hline $4 a$ & Benthic protection & 1660.92 & 0.96 \\
\hline $1 b$ & & 6089.63 & 0.82 \\
\hline $2 b$ & & 6185.98 & 0.83 \\
\hline $3 b$ & & 6377.81 & 0.81 \\
\hline $4 b$ & No-take & 5230.69 & 0.84 \\
\hline $4 b$ & Benthic protection & 1756.12 & 0.95 \\
\hline $1 \mathrm{c}$ & & 8214.66 & 0.75 \\
\hline $2 c$ & & 8498.42 & 0.76 \\
\hline $3 c$ & & 8696.41 & 0.74 \\
\hline $4 c$ & No-take & 7435.62 & 0.78 \\
\hline $4 c$ & Benthic protection & 2627.64 & 0.93 \\
\hline
\end{tabular}

Table S4: Best solution inside designated MPAs in each of the scenarios.

\begin{tabular}{cccc} 
Scenario & $\begin{array}{c}\text { Total area } \\
\text { to protect }\end{array}$ & $\begin{array}{c}\text { Total area } \\
\text { already protected* }\end{array}$ & $\begin{array}{c}\text { Percentage } \\
\text { already protected }\end{array}$ \\
\hline 1a & 4156.24 & 1271.50 & 30.59 \\
1b & 6089.63 & 1496.98 & 24.58 \\
1c & 8214.66 & 1755.54 & 21.37 \\
2a & 4253.19 & 1115.18 & 26.22 \\
2b & 6185.98 & 1515.71 & 24.50 \\
2c & 8498.42 & 2027.69 & 23.86 \\
3a & 4636.77 & 1157.31 & 24.96 \\
3b & 6377.81 & 1403.15 & 22.00 \\
3c & 8696.41 & 2102.02 & 24.17 \\
4a & 5237.69 & 1092.06 & 20.85 \\
4b & 6981.85 & 1496.55 & 21.43 \\
4c & 10059.62 & 2423.31 & 24.09 \\
\hline
\end{tabular}

*benthic protection is not guaranteed 
Table S5: Summary table of environmental variables used in spatial modeling and Marxan analysis.

\section{Environmental}

\begin{tabular}{|c|c|c|c|}
\hline variables & Units & Dataset origin & Website \\
\hline $\begin{array}{l}\text { Chlorophyll-a } \\
\text { concentration (CHL) }\end{array}$ & $\mathrm{mg} \mathrm{C} \mathrm{m-3}$ & Aqua MODIS sensor & http://oceancolor.gsfc.nasa.gov \\
\hline $\begin{array}{l}\text { Sea surface } \\
\text { temperature (SST) } \\
\text { Depth }\end{array}$ & $\stackrel{\circ}{C}$ & Aqua MODIS sensor & http://oceancolor.gsfc.nasa.gov \\
\hline (DEPTH) & $\mathrm{m}$ & ETOPO website & www.ngdc.noaa.gov/mgg/global/global.htm \\
\hline $\begin{array}{l}\text { Dissolved-oxygen (DO) } \\
\text { Sea surface salinity } \\
\text { (SSS) }\end{array}$ & $\mathrm{ml} \mathrm{l-1}$ & $\begin{array}{l}\text { Bio-Oracle Project } \\
\text { Bio-Oracle Project }\end{array}$ & www.oracle.ugent.be \\
\hline \multicolumn{4}{|l|}{ Marxan threat layers } \\
\hline Fishing activity & Fishing AIS data & $\begin{array}{l}\text { Global Fishing Watch } \\
\text { database }\end{array}$ & https://globalfishingwatch.org/datasets-and-code/ \\
\hline SST anomalies & rescaled data $[0-1]$ & Halpern et al. (2015) & *Halpern et al. (2015) Supplementary material \\
\hline Pesticides & rescaled data $[0-1]$ & Halpern et al. (2015) & *Halpern et al. (2015) Supplementary material \\
\hline Fertilizers & rescaled data $[0-1]$ & Halpern et al. (2015) & *Halpern et al. (2015) Supplementary material \\
\hline Ocean pollution & rescaled data $[0-1]$ & Halpern et al. (2015) & *Halpern et al. (2015) Supplementary material \\
\hline Inorganic pollution & rescaled data $[0-1]$ & Halpern et al. (2015) & *Halpern et al. (2015) Supplementary material \\
\hline
\end{tabular}

*https://knb.ecoinformatics.org/view/doi:10.5063/F19Z92TW 


\section{Literature Cited}

Cheung, W.W.L., Pitcher, T.J., Pauly, D., 2005. A fuzzy logic expert system to estimate intrinsic extinction vulnerabilities of marine fishes to fishing. Biol. Conserv. 124, 97-111. https://doi.org/10.1016/j.biocon.2005.01.017

Halpern, B.S., Frazier, M., Potapenko, J., Casey, K.S., Koenig, K., Longo, C., Lowndes, J.S., Rockwood, R.C., Selig, E.R., Selkoe, K.A., Walbridge, S., 2015. Spatial and temporal changes in cumulative human impacts on the world's ocean. Nat. Commun. 6, 7615. https://doi.org/10.1038/ncomms8615

Mazor, T., Possingham, H.P., Edelist, D., Brokovich, E., Kark, S., 2014. The crowded sea: Incorporating multiple marine activities in conservation plans can significantly alter spatial priorities. PLoS One 9, e104489. https://doi.org/10.1371/journal.pone.0104489 